\title{
Vascular Extracellular Matrix Remodeling and Hypertension
}

\author{
Zeyu Cai, ${ }^{1,2}$ Ze Gong, ${ }^{1,2}$ Zhiqing Li, ${ }^{1,2}$ Li Li, $^{1,2}$ and Wei Kong ${ }^{1,2}$
}

\begin{abstract}
Significance: The vascular extracellular matrix (ECM) not only provides mechanical stability but also manipulates vascular cell behaviors, which are crucial for vascular function and homeostasis. ECM remodeling, which alters vascular wall mechanical properties and exposes vascular cells to bioactive molecules, is involved in the development and progression of hypertension.

Recent Advances: This brief review summarized the dynamic changes in ECM components and their modification and degradation during hypertension and after antihypertensive treatment. We also discussed how alterations in the ECM amount, assembly, mechanical properties, and degradation fragment generation provide input into the pathological process of hypertension.

Critical Issues: Although the relevance between ECM remodeling and hypertension has been recognized, the underlying mechanism by which ECM remodeling initiates the development of hypertension remains unclear. Therefore, the modulation of ECM remodeling on arterial stiffness and hypertension in genetically modified rodent models is summarized in this review. The circulating biomarkers based on ECM metabolism and therapeutic strategies targeting ECM disorders in hypertension are also introduced.

Future Directions: Further research will provide more comprehensive understanding of ECM remodeling in hypertension by the application of matridomic and degradomic approaches. The better understanding of mechanisms underlying vascular ECM remodeling may provide novel potential therapeutic strategies for preventing and treating hypertension. Antioxid. Redox Signal. 34, 765-783.
\end{abstract}

Keywords: hypertension, extracellular matrix, stiffness, remodeling, vascular smooth muscle cell

\section{Introduction}

T HE RISK FACTORS FOR HYPERTENSION include aging, obesity, smoking, alcoholism, cold stress, potassium intake deficiency, a high-salt diet, etc. $(12,53,84,87,117$, $119,182)$. Long-term hypertension results in the elevated pressures on vascular walls and cardiac chambers, systemic vascular remodeling, atherothrombosis, and atherosclerosis, etc., thereby damaging target organs such as the heart, brain, and kidneys (118). A number of reviews have summarized the process and characteristics of vascular remodeling during hypertension (92). In brief, increased peripheral resistance is related to structural alterations in resistance vessels, mainly characterized by vascular smooth muscle cell (VSMC) proliferation and hypertrophy, stenosis of the lumen, and an increase in the media/lumen ratio. In addition, the large arteries exhibit increased stiffness and loss of compliance, which is monitored by the pulse wave velocity (PWV). These characteristics of vascular remodeling in hypertension are typically associated with an imbalance in the renin-angiotensin-aldosterone system, endothelial cell (EC) dysfunction, and contractile properties and phenotypic switching of VSMCs, as well as with extracellular matrix (ECM) reorganization and inflammation throughout the entire vessel wall.

The vascular ECM is well known for its ability to form an intricate three-dimensional network that provides mechanical support for various cell types and maintains vascular wall integrity. The ECM also actively integrates extracellular signals and influences resident cell physiology. In addition, the mechanical characteristics of the ECM, including its elasticity, strength, and deformability, provide inputs into

\footnotetext{
${ }^{1}$ Department of Physiology and Pathophysiology, School of Basic Medical Sciences, Peking University, Beijing, China.

${ }^{2}$ Key Laboratory of Molecular Cardiovascular Science, Ministry of Education, Beijing, China.
} 
cell behaviors (160). During vascular remodeling in hypertension, the ECM undergoes profound alterations characterized mainly by elastic fiber fragmentation and excessive collagen deposition as well as the rearrangement of matricellular proteins and proteoglycans (PGs) (14). Recent studies have also concluded that not only the quantity but also the quality of the ECM, including correct assembly, appropriate crosslinking, and the synthesis/degradation balance, plays a pivotal role in hypertension-associated vascular remodeling (3).

\section{ECM Components and Homeostasis in the Vascular Wall}

ECM proteins are the major noncellular components in the vascular wall (62). Identification of vascular ECM components is essential for revealing the dynamic structural and functional characterization under physiological and pathological conditions. Matridomics is defined as a proteomics approach to catalog the ECM components present in tissues, and provide comprehensive information about the quantity and quality of ECM proteins (31). This approach includes extraction of decellularized ECM fraction, solubilization and deglycosylation of ECM proteins, and analysis by liquid chromatography tandem mass spectrometry $(5,35)$. The Mayr laboratory has utilized the matridomics approach and identified 103 different ECM proteins in the human aorta, mainly elastin, collagens, glycoproteins, and PGs, as well as proteases and their inhibitors (35).

The composition of ECM components varies in distinct layers of the vascular wall. Type IV collagen, along with type XV collagen, type XVIII collagen, laminin, nidogen, perlecan, agrin, and fibronectin, are assembled into a mesh-like structure named the basement membrane (BM), which provides an anchoring site for ECs in the tunica intima (83). Elastin contributes to the formation of the internal elastic lamina (IEL), which separates the tunica intima from the tunica media. In the middle layer, elastin is deposited on the microfibril scaffold, which is composed of fibrillins and proteins involved in fiber formation, including microfibrilassociated glycoproteins (MAGPs), microfibrillar-associated proteins (MFAPs), and fibulins. Elastin is crosslinked by lysyl oxidase (LOX) to form the three-dimensional lamellar network. The contractile smooth muscle cells and elastic fibers are arranged into concentric circles, constituting a recoiling functional unit of the vascular wall, and endowing arteries with elasticity to expand and retract during the cardiac cycle $(3,97)$. Type I, III, V, and VI collagen fibers, fibronectin, laminin, PGs, and glycoproteins are also interposed between fenestrated lamellar layers $(134,177)$. The major ECM components in the tunica adventitia are type I and III fibrillar collagens, chondroitin sulfate, and dermatan sulfate PGs, fibronectin, and many other ECM proteins produced by adventitial fibroblasts (177). Fibrillar collagens secreted into the tunica media and tunica adventitia aggregate into quarter-staggered fibrils and are crosslinked by LOX, limiting excessive vasodilation and endowing arteries with strength. The vascular ECM also contains nonstructural matricellular proteins-including thrombospondins (TSPs), tenascin C (TNC), osteopontin (OPN), secreted protein, acidic and rich in cysteine (SPARC), etc.- that regulate cell adhesion, migration, proliferation, and cytokine-related responses (Fig. 1).

Most ECM components in the vascular wall are not static but rather highly dynamic, constantly undergoing production, degradation, and organization to maintain vascular homeostasis. Proteases that hydrolyze ECM proteins include matrix metalloproteinases (MMPs), members of the disintegrin and metalloproteinase (ADAM) and a disintegrin and metalloproteinase with thrombospondin motifs (ADAMTS) families, serine proteases (e.g., plasmin, neutrophil-elastase, and cathepsin G), cysteine proteases (e.g., cathepsin B, L, and S), and aspartyl proteases (cathepsin D) (70). In vascular tissues, elastic fibers can be degraded by MMP-2, MMP-7, MMP-9, and MMP-12, and collagens are mainly degraded by MMP-1, MMP-8, MMP-13, and MMP-18 (80, 137). The activity of MMPs is inhibited by endogenous tissue inhibitors of metalloproteinases (TIMPs). Vascular ECM turnover is regulated by MMP and TIMP equilibrium, and dysregulation of the MMP/TIMP ratio leads to impaired ECM homeostasis. Degradomics is defined as the genomic and proteomic approaches to reveal the proteases and their inhibitors, substrates, and interactors. Degradomics requires highthroughput, high-content techniques such as terminal amine isotopic labeling of substrates (TAILS) and combined fractional diagonal chromatography that allow the identification and quantification of proteases and the proteolytic-cleavage fragments $(40,103)$. The Mayr laboratory has identified substrates for MMP-3, MMP-9, MMP-12, and MMP-14 in human vasculature by using degradomics $(36,153)$. However, more comprehensive analyses of the substrates for proteases beyond the commonly studied MMPs using degradomics are needed.

\section{Vascular ECM Alterations in Hypertension and Hypertension-Associated Vascular Remodeling}

Alterations in ECM production, degradation, and organization in arterial layers are important features of hypertensive vascular remodeling (Fig. 1). Changes in ECM components can be triggered by increased circumferential wall stress, growth factors, inflammatory cytokines, chemokines, oxidative stress, and other pathological processes (95).

\section{Alterations in ECM components}

Elastin is the most predominant ECM constituent in the middle layer of large elastic arteries and determines the mechanical properties of the vascular wall (166). Elastin fibers are prone to fragmentation and rupture in age-related arterial stiffness and hypertension. Pathogenic factors related to aging, such as mechanical fracture, calcification, exposure to glycation/carbamylation products, and peroxidation, facilitate the susceptibility of elastin to degradation by serine and cysteine proteases and MMPs (43). Reduced elastin amounts were observed in stroke-prone spontaneously hypertensive rats (SHR-SP) (78). Since the elastases mentioned above are partially produced by inflammatory cells such as polymorphonuclear neutrophils and macrophages, the activated immune and inflammatory reactions in arterial walls may contribute to increased elastoproteolysis and subsequent elastin degradation $(114,170)$. In contrast to the above observations, augmented elastin production in response to mechanical stress was observed at the very early stage of 


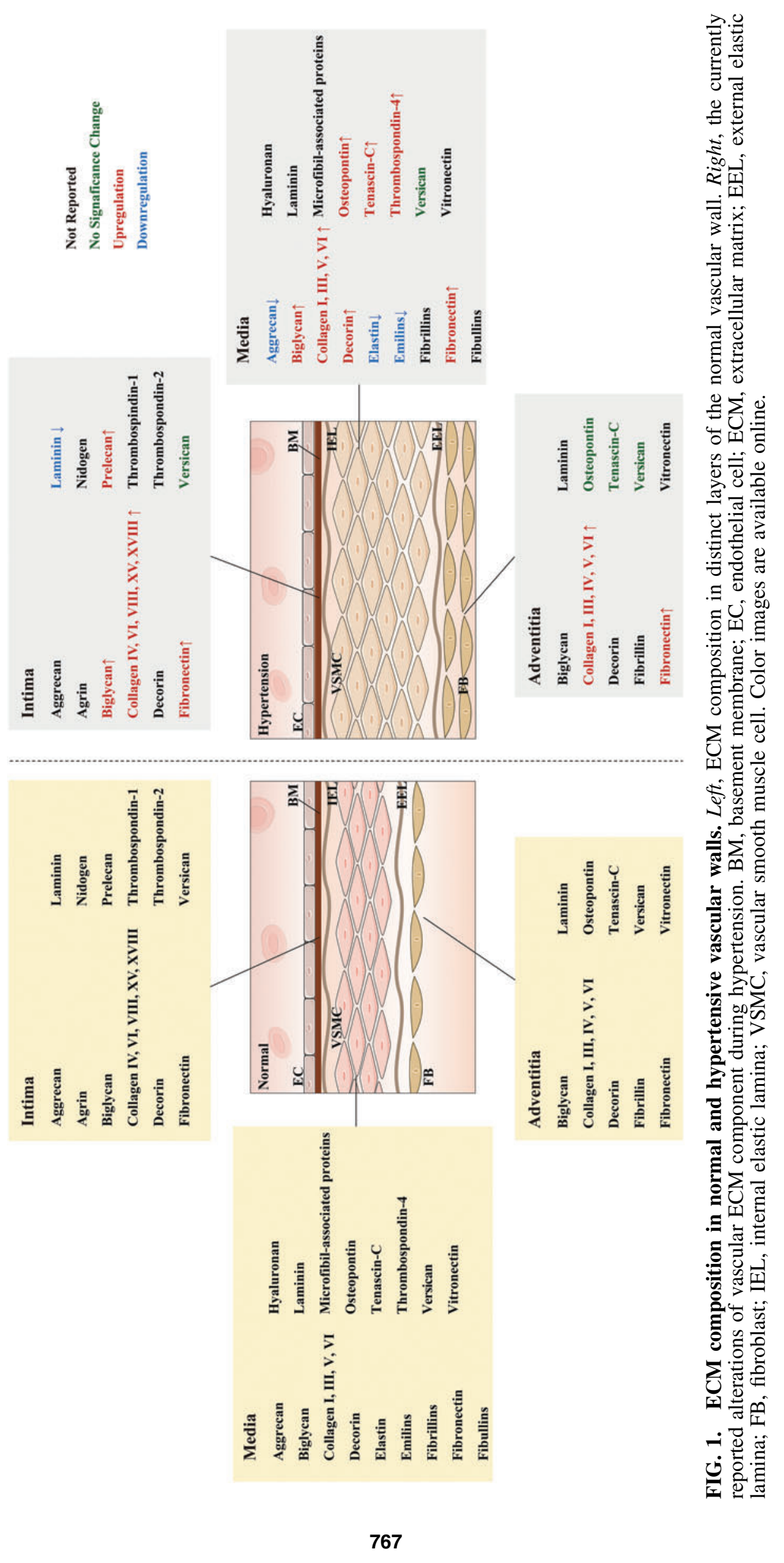


hypertension in deoxycorticosterone acetate (DOCA)-salt, renal clipped, Dahl/salt-sensitive rats (86). However, this newly synthesized tropoelastin cannot be assembled into mature elastin fibers and fails to provide entropic elasticity $(3,90,161)$.

Collagen is another basic structural element in vascular walls that limits excessive vasodilation. Increased deposition of collagen I, III, and IV in the vascular wall has been reported in both conduit and resistance arteries from patients with essential hypertension (75) as well as in experimental murine models of hypertension $(15,164)$. Accumulating evidence has shown the prohypertensive factors and the downstream signaling pathways involved in excessive production of collagens. Examples include transforming growth factor- $\beta$ (TGF- $\beta$ )-stimulated Smad $2 / 3$ and mitogen-activated protein kinase (MAPK) pathways; angiotensin II (Ang II)activated activator protein-1 (AP-1), protein kinase $\mathrm{C}$ (PKC), and p38MAPK signaling; and cyclic stretch-triggered c-Jun N-terminal kinase (JNK), extracellular signal-regulated kinase (ERK) $1 / 2$, and nuclear factor $-\kappa \mathrm{B}(\mathrm{NF}-\kappa \mathrm{B})$ pathways in VSMCs and fibroblasts $(64,95)$. Recently, Wu et al. performed a cell sorting and lineage tracing study to explore the cellular origin of matrix production during hypertension. They showed that adventitial collagen production is not attributable only to resident fibroblasts; adventitial Sca- $1^{+}$ progenitor cells also acquire a fibroblast-like phenotype and are able to produce collagen. Bone marrow-derived cells account for $\sim 60 \%$ of the matrix-producing Sca- $1^{+}$cells, whereas the EC lineage accounts for $24 \%$ and the VSMC lineage does not contribute to this population (175).

In addition to the notable alterations in structural components, changes in some nonstructural proteins, including glycosaminoglycans, PGs, and matricellular proteins, occur during hypertensive vascular remodeling. Fibronectin (9) and its alternatively spliced forms (159), OPN (168), large chondroitin sulfate PG, large heparan sulfate PG, biglycan (PGI), and decorin (PGII) are upregulated in the arteries of spontaneously hypertensive rat (SHR) (167). TNC expression is markedly elevated in DOCA-salt-induced hypertensive mice and $\operatorname{SHR}(42,74,111)$. In $\mathrm{L}^{-\mathrm{N}^{\mathrm{G}}}$-nitro arginine methyl ester (L-NAME)-induced hypertensive rats, similar upregulation of TNC is found in the aorta, but the level of TNC is decreased in small mesenteric arteries (11). Clinical studies also showed increased serum levels of both $\mathrm{B}$ and $\mathrm{C}$ domain-containing TNC in patients with arterial hypertension (54).

In the past decade, proteomic approaches have provided comprehensive information on molecular features in cardiovascular diseases and advanced the understanding of ECM components involved in the fibrotic process (32). Proteomic studies have been increasingly applied in hypertension patients and experimental models, and several differentially expressed proteins have been identified $(23,32,51,109)$. A quantitative serum proteomic analysis using the isobaric tags for relative and absolute quantification method identified 101 differentially expressed proteins between the essential hypertension group and the healthy control group. Only 3\% of the differentially expressed proteins were ECM proteins in the serum, and the changes included decreased expression of cartilage oligomeric matrix protein (COMP) and increased expression of fibulin-5 (178). Recently, a proteomic study on left mammary artery samples from patients with elevated PWV quantitated 38 ECM molecules. Compared with the normal PWV group, the high PWV group exhibited upregulation of collagen type VIII $\alpha 1$, collagen type VIII $\alpha 2$, and collagen type IV $\alpha 1$. In addition, three members of the small leucine-rich proteoglycan (SLRP) family, including prolargin, asporin, and mimecan, which serve as regulators of collagen deposition and arrangement, were downregulated in the high PWV group (109). Proteomic analysis of aortic walls in SHR showed a decreased protein level of mimecan after 6 weeks of load-free swimming training (51). However, current proteomic data on vascular ECM alterations are primarily based on the analysis of total protein extracted from artery samples. Extraction of decellularized vascular ECM combined with matrix proteomic studies is expected to provide unprecedented insights into ECM remodeling in hypertension (Table 1).

\section{Alterations in the ECM topological arrangement}

Not only the biochemical composition but also the topological arrangement of the ECM is altered in response to hypertensive stimuli. Chow et al. described the organization, realignment, and recruitment of elastin and collagen in response to mechanical loading by using a multiphoton imaging method. Medial collagen fibers display a wavy configuration in the static state, and exhibit engagement and circumferential distribution throughout the stretching process. Adventitial collagen, originally existing as larger wavy bundles of fibers, begins to strengthen at $>20 \%$ strain. Realignment of collagen fibers toward the major direction of loading occurs in both the medial and adventitial layers in response to unequal biaxial loading. Medial elastin fibers start to straighten at the onset of loading but plateau at $>20 \%$ strain (29). Another study also revealed the dimensional structural alterations in elastin and collagen fibers in the thoracic aorta during pressurization. Increased intraluminal pressure in the mouse aorta leads to reduced waviness of collagen fibers. The collagen fibers in smooth muscle-rich layers are more likely to strengthen than those in the elastic lamina (158). Therefore, pressurizationinduced topological alterations are multifaceted due to the heterogeneity of vascular layers and the different mechanical properties of collagen and elastin.

The construction of the vascular topological structure depends on the biological behavior of VSMCs as well as the elaborate regulation of the ECM constituent assembly. Hays et al. found that collagen cultured with VSMCs from the Wistar-koyto rat thoracic aorta displays a parallel alignment, whereas collagen cultured with VSMCs from SHR exhibits shorter fragments, disorganization with greater alignment angles, and a multidirectional orientation (65). Matrix fibronectin controls the organization and assembly of other matrix proteins, and removal of polymerized fibronectin from decellularized ECM markedly reduces the deposition of collagen I and TNC. Fibronectin accumulation is observed in the large arteries of hypertensive rats (9), thus providing a scaffold to facilitate the excessive assembly and deposition of collagens I and IV, laminin, and TNC (67). LOX regulates the crosslinking of both elastin and collagen during fiber assembly; thus, dysregulation of LOX expression and activity alters the topological structure and mechanical properties of the vascular ECM. An increase in vascular LOX activity has been reported in SHR and Ang II-infused hypertensive mice, resulting in an increase in crosslinked elastin and collagen fibers $(46,113)$. Treatment with the LOX inhibitor 
Table 1. Vascular Extracellular Matrix Alterations in Hypertension

\begin{tabular}{|c|c|c|c|c|}
\hline Classification & ECM proteins & Detection method & Alterations & References \\
\hline \multirow[t]{4}{*}{ Elastic fiber } & \multirow[t]{2}{*}{ Elastin } & $\begin{array}{l}\text { Isolation of insoluble } \\
\text { elastin }\end{array}$ & $\begin{array}{l}\text { Decreased elastin content and increased } \\
\text { elastase-like enzyme activity in } \\
\text { 20-week-old SHRs }\end{array}$ & (78) \\
\hline & & $\begin{array}{l}\text { Isolation of insoluble } \\
\text { elastin }\end{array}$ & $\begin{array}{l}\text { Augmented elastin production at the early } \\
\text { stage of hypertension in DOCA salt- } \\
\text { induced hypertensive rats }\end{array}$ & (86) \\
\hline & Fibullin-5 & Proteomics & $\begin{array}{l}\text { Increase in serum from patients with } \\
\text { essential hypertension }\end{array}$ & $(178)$ \\
\hline & LOX & Western blot & $\begin{array}{l}\text { Increase in SHRs and Ang II-induced } \\
\text { hypertensive mice }\end{array}$ & $(46,113)$ \\
\hline \multirow[t]{4}{*}{ Collagens } & \multirow[t]{3}{*}{ Collagen } & Electron microscopy & $\begin{array}{l}\text { Increased density of collagen in resistance } \\
\text { arteries from patients with essential } \\
\text { hypertension }\end{array}$ & $(75)$ \\
\hline & & $\begin{array}{l}\text { Picrosirius red staining } \\
\text { Western blot }\end{array}$ & $\begin{array}{l}\text { Increased total collagen content and the } \\
\text { ratio of collagen I/III in resistance } \\
\text { arteries from ouabain-induced } \\
\text { hypertensive rats }\end{array}$ & $(15)$ \\
\hline & & Confocal microscopy & $\begin{array}{l}\text { Increased collagen deposition in } \\
\text { mesenteric arteries from Ang II-infused } \\
\text { hypertensive mice }\end{array}$ & $(164)$ \\
\hline & $\begin{array}{l}\text { Collagen IV, } \\
\text { collagen VIII }\end{array}$ & Proteomics & $\begin{array}{l}\text { Increase in left mammary artery from } \\
\text { patients with elevated PWV }\end{array}$ & $(109)$ \\
\hline \multirow[t]{2}{*}{ GPs } & \multirow[t]{2}{*}{ Fibronectin } & Immunohistochemistry & Increase in SHR aorta & (9) \\
\hline & & Northern blot & $\begin{array}{l}\text { Increased alternative spliced forms in } \\
\text { aorta from DOCA-salt-induced } \\
\text { hypertensive rats and SHRs }\end{array}$ & $(159)$ \\
\hline Proteoglycans & $\begin{array}{l}\text { Large chondroitin } \\
\text { sulfate PG. large } \\
\text { heparan sulfate } \\
\text { PG, biglycan, } \\
\text { decorin }\end{array}$ & $\begin{array}{l}\text { DEAE anion-exchange } \\
\text { chromatography and } \\
\text { SDS-PAGE }\end{array}$ & Increase in SHR arteries in vitro & $(167)$ \\
\hline \multirow[t]{2}{*}{ PG } & $\begin{array}{l}\text { Prolargin, asporin, } \\
\text { mimecan }\end{array}$ & Proteomics & $\begin{array}{l}\text { Decrease in left mammary artery from } \\
\text { patients with elevated PWV }\end{array}$ & (78) \\
\hline & Mimiecan & Proteomics & $\begin{array}{l}\text { Decrease in aortic wall from SHRs after } \\
\text { 6-week swimming training }\end{array}$ & $(86)$ \\
\hline \multirow[t]{7}{*}{$\begin{array}{l}\text { Matricellular } \\
\text { proteins }\end{array}$} & TSP-1 & $\begin{array}{l}\text { Quantitative sandwich en- } \\
\text { zyme immunoassays }\end{array}$ & $\begin{array}{l}\text { Decreased plasma levels in patients } \\
\text { with hypertension and restored after } \\
\text { treatment }\end{array}$ & (19) \\
\hline & TSP-4 & $\begin{array}{l}\text { Western blot, mRNA } \\
\text { microarray, real-time PCR }\end{array}$ & Increase in mesenteric arteries from SHRs & $(130)$ \\
\hline & COMP & Proteomics & $\begin{array}{l}\text { Decrease in serum from patients with } \\
\text { essential hypertension }\end{array}$ & $(178)$ \\
\hline & \multirow[t]{2}{*}{ OPN } & Immunoenzymatic assay & $\begin{array}{l}\text { Increase in plasma from patients with } \\
\text { hypertension }\end{array}$ & $(155)$ \\
\hline & & $\begin{array}{l}\text { Immunohistochemistry, } \\
\text { Western blot, ELISA }\end{array}$ & $\begin{array}{l}\text { Increase in plasma and aorta from SHR } \\
\text { and Ang II- or L-NAME-induced } \\
\text { hypertensive mice }\end{array}$ & $(145)$ \\
\hline & SPARC & $\begin{array}{l}\text { Immunohistochemistry, } \\
\text { in situ hybridization }\end{array}$ & $\begin{array}{l}\text { Increase in blood vessels from Ang II- } \\
\text { infused rats }\end{array}$ & (133) \\
\hline & TNC & Immunohistochemistry & $\begin{array}{l}\text { Increase in artery from DOCA-salt- } \\
\text { induced hypertensive mice and SHRs }\end{array}$ & $(42,111)$ \\
\hline
\end{tabular}

Ang II, angiotensin II; COMP, cartilage oligomeric matrix protein; DOCA, deoxycorticosterone acetate; ECM, extracellular matrix; ELISA, enzyme-linked immunosorbent assay; GP, glycoprotein; L-NAME, L-N ${ }^{\mathrm{G}}$-Nitro arginine methyl ester; LOX, lysyl oxidase; mRNA, messenger RNA; OPN, osteopontin; PCR, polymerase chain reaction; PG, proteoglycan; PWV, pulse wave velocity; SDS-PAGE, sodium dodecyl sulfate-polyacrylamide gel electrophoresis; SHR, spontaneously hypertensive rat; SPARC, secreted protein, acidic and rich in cysteine; TNC, tenascin C; TSP, thrombospondin.

$\beta$-aminopropionitrile (BAPN) ameliorates the development of hypertension (79). Another collagen crosslinking enzyme named transglutaminase 2 (TG2) can be activated by the increased production of TGF- $\beta$ and decreased production of nitric oxide (NO), thereby promoting additional collagen crosslinking (156).

\section{Imbalance between proteases and their inhibitors}

Accelerated turnover and deposition of extracellular collagens is observed in essential hypertension. Procollagen type I C-terminal propeptide (PICP) and carboxy-terminal telopeptide of type I collagen (ICTP) are considered markers 
for type I collagen synthesis and degradation, respectively. The PICP/ICTP ratio is increased in the serum of SHR compared with that of control rats, supporting the increased synthesis/degradation ratio of type I collagen in hypertension (38). Abnormally high serum concentrations of PICP are also observed in patients with essential hypertension (39). Previous studies reported that excessive arterial collagen deposition in hypertension may be facilitated by diminished MMP activity.

Decreased serum MMP-1 levels together with increased TIMP-1 concentrations were observed in patients with hypertension (93). Activity of MMP-1 and MMP-9 and expression of the MMP inducer and activator proteins in internal mammary artery are downregulated in hypertensive patients undergoing coronary artery bypass grafting surgery (48). MMP-3 activity in resistance arteries of SHR was also decreased, thus facilitating the accumulation of fibronectin and PGs (24). However, accumulating data indicate the increased MMP expression and activity in the development of hypertension. In patients with isolated systolic hypertension, serum levels of MMP-2 and MMP-9 are increased, and MMP-9 levels positively correlate with aortic stiffness (184). Niemirska et al. found that plasma MMP-9 and TIMP-1 concentrations and the MMP-9/TIMP-1 ratio are significantly elevated in children with untreated primary hypertension, and that there are significant positive correlations between arterial stiffness and the TIMP-1 concentration (123). Odenbach et al. reported that MMP-2 activity in the aorta is upregulated in Ang II-infused mice and is involved in the maintenance of agonist-induced arterial constriction (125). The discrepancy in changes of MMPs in hypertension may attribute to the following aspects. Plasma levels of
MMPs may vary with different stages, the severity of hypertension, and the occurrence of hypertension-related complications. Examples are the decreased MMP activity in young SHR-SP vessels, whereas increased vascular MMP activity in the older hypertensive rats $(76,151)$; the higher pro-MMP2 activity in hypertensive patients with heart failure (HF) than in those without HF (56). Furthermore, plasma or serum levels of MMPs represent their global expression, and the changes of MMPs in specific vasculature need to be evaluated additionally.

ADAMTS-1, a PG-degrading enzyme, is upregulated by Ang II and proinflammatory factors in ECs and VSMCs and by vascular endothelial growth factor (VEGF) in ECs. These stimuli strongly implicated in vascular remodeling enhance the binding of nuclear factor of activated T-cells (NFAT) or CCAAT-enhancer-binding protein $\beta(\mathrm{C} / \mathrm{EBP} \beta)$ to the ADAMTS-1 promoter (126). Cathepsin L/V protein levels are upregulated in the mesenteric arteries and serum of patients with hypertension, and their activity is augmented in Ang II-induced hypertensive mice. Ang II stimulation induces the release of lysosomal cathepsin B in THP-1 cells, which leads to NOD, LRR, and pyrin domaincontaining protein 3 (NLRP3) inflammasome activation, decreased NO release, and macrophage digestion dysfunction. Inhibition of cathepsin B abrogates Ang II-induced NLRP3 inflammasome activation and macrophage dysfunction, thus revealing the involvement of cathepsin B in the sterile inflammatory response to Ang II (100). Plasma cathepsin D levels were inversely associated with endothelial-dependent vasodilation in the Prospective Investigation of the Vasculature in Uppsala Seniors (PIVUS) study (102) (Table 2).

\section{Table 2. Vascular Protease Alterations in Hypertension}

\begin{tabular}{|c|c|c|c|c|}
\hline Classification & Protease & Substrates & Alterations & References \\
\hline \multirow[t]{4}{*}{ MMPs } & MMP-9 & $\begin{array}{l}\text { Collagen, gelatin, elastin, } \\
\text { fibronectin }\end{array}$ & $\begin{array}{l}\text { Decreased plasma levels in patients } \\
\text { with essential hypertension and } \\
\text { restored after treatment; increased } \\
\text { gelatinase activity in Ang II-infused } \\
\text { mice; positively related with human } \\
\text { aortic PWV }\end{array}$ & $\begin{array}{l}(52,127 \\
184,188)\end{array}$ \\
\hline & MMP-2 & $\begin{array}{l}\text { Collagen, gelatin, elastin, } \\
\text { fibronectin }\end{array}$ & $\begin{array}{l}\text { Decreased plasma levels in patients } \\
\text { with essential hypertension; } \\
\text { increased gelatinase activity in } \\
\text { Ang II-infused mice and DOCA- } \\
\text { salt-induced hypertensive rats }\end{array}$ & $(52,174,184)$ \\
\hline & MMP-1 & $\begin{array}{l}\text { Collagen, entactin, PGs, } \\
\text { ovostatin, MMP-2, } \\
\text { MMP-9, pro-MMP-9 }\end{array}$ & $\begin{array}{l}\text { Decreased serum levels in patients } \\
\text { with hypertension and restored after } \\
\text { lisinopril treatment }\end{array}$ & (93) \\
\hline & MMP-7 & $\begin{array}{l}\text { Collagen, gelatin, fibro- } \\
\text { nectin, laminin, elastin, } \\
\text { transferrin. casein }\end{array}$ & $\begin{array}{l}\text { Increased in PE-, Ang II-, and } \\
\text { L-NAME-induced hypertensive rats }\end{array}$ & $(171)$ \\
\hline ADAMs & $\begin{array}{l}\text { ADAM-17/ } \\
\text { TACE }\end{array}$ & $\begin{array}{l}\text { Collagen, GPs, Notch1, } \\
\text { vasorin, APP, etc. }\end{array}$ & $\begin{array}{l}\text { Increase in SHR and Ang II-treated } \\
\text { VSMCs }\end{array}$ & $(124,172,192)$ \\
\hline \multirow[t]{2}{*}{ Cathepsins } & Cathepsin D & & $\begin{array}{l}\text { Elevated gradually with increasing BP } \\
\text { in SHR }\end{array}$ & $(180)$ \\
\hline & $\begin{array}{l}\text { Cathepsin } \\
\mathrm{L} / \mathrm{V}\end{array}$ & & $\begin{array}{l}\text { Increased in the mesenteric arteries } \\
\text { and serum from patients with } \\
\text { hypertension; augmented activity in } \\
\text { Ang II-induced hypertensive mice }\end{array}$ & (82) \\
\hline
\end{tabular}

ADAM, a disintegrin and metalloproteinase; APP, amyloid precursor protein; BP, blood pressure; MMP, matrix metalloproteinase; PE, phenylephrine; TACE, tumor necrosis factor-alpha-converting enzyme; VSMC, vascular smooth muscle cell. 


\section{Vascular ECM Remodeling Is Involved in Hypertension}

Changes in constituents and topology in the vascular wall ECM have been implicated in the pathogenesis of hypertension. Gene mutations in populations and genetically modified rodent models provide evidence that the ECM is involved in mediating arterial stiffness, vascular cell function and behavior, and inflammatory and oxidative events.

\section{Genetically modified animal models}

Mutation and modification of genes related to elastin and related fibrillar proteins (fibulin, fibrillin, emilin1), collagens, proteases and their inhibitors, and matricellular proteins have revealed phenotypic changes in the arterial wall architecture and blood pressure (BP) fluctuations (Table 3).

\section{ECM remodeling and vascular stiffness}

Arterial stiffness develops with aging and other pathological states, and is primarily caused by ECM remodeling, smooth muscle cell adhesion and stiffness, calcification of the elastic lamellae, and elevated transmural distending pressure (143). In recent years, the increased stiffness of large elastic arteries in hypertension has received increasing attention and is recognized as a risk factor for cardiovascular disease morbidity and mortality, which can be reflected by the PWV (116). During hypertension, increased arterial stiffness can be detected at the very early stage, predicting the subsequent process of BP elevation and target organ damage in hypertension (120).

The stiffness of large arteries is mainly determined by collagen and elastin, the two most abundant ECM components in vascular walls. Mutations in the collagen III gene (COL3A1) lead to Ehlers-Danlos syndrome, which is characterized by vascular dilation and aortic rupture (21). In contrast, excessive collagen deposition is deleterious to the vascular wall and increases stiffness. Stakos et al. reported that patients with hypertension have increased levels of procollagen type I N-terminal propeptide (PINP)/collagen type I carboxy-terminal telopeptide (CITP), which indicates increased collagen synthesis and is positively associated with PWV (152). In addition, You et al. revealed a positive correlation of PWV with the relative content of collagen and a negative correlation with the relative content of elastin in ascending aorta specimens from hypertension patients (185). Elastin haploinsufficiency is sufficient to reduce arterial compliance and elevate BP in mice (50). Martinez-Revelles et al. revealed the effect of improper crosslinking of elastin on arterial stiffness in a mouse model of LOX overexpression in VSMCs. Elevated LOX expression and activity lead to increased insoluble elastin deposition and increased elastin assembly with smaller fenestrae in the IEL, which in turn increases arterial stiffness (113).

Collagen and elastin are not the only ECM components determining arterial stiffness. Deposition of fibronectin, fibulin, glycosaminoglycan, and PGs also influences the mechanical properties of the arterial wall, including stiffness (191). Fibronectin polymerization occurs after its addition to cell-embedded collagen biogels, and induces increases in tensile strength and toughness (57). Although no changes in the collagen and elastin densities were observed in aldosterone-salt hypertensive rats, aldosterone induced arterial fibronectin accumulation and increased the intrinsic carotid stiffness (122). Another study using sinoaortic denervated (SAD) rats showed that enhanced arterial thickness and stiffness are associated with increased VSMC attachment to the surrounding ECM via fibronectin and its $\alpha_{5} \beta_{1}$ integrin receptor (10). Hyaluronan transgenic (Tg) mice exhibit an increased aortic cross-sectional area, and enhanced arterial stiffness and strength. Excessive accumulation and crosslinking of hyaluronan in the tunica media leads to a shift in the smooth muscle cell (SMC) phenotype, showing increased proliferation and osteoprotegerin production (107). A recent study identified the association of aggrecan (ACAN) and fibulin-1 (FBLN-1) polymorphisms with the aortic PWV in young healthy adults. Both aggrecan and fibulin- 1 are downregulated in aortas from donors with high arterial stiffness and systolic BP, suggesting their reduced expression in facilitating age-related aortic stiffening (183).

\section{ECM remodeling and VSMC biology}

Multiple prohypertensive factors, such as mechanical stretching and exposure to growth factors, cytokines, and hormones, lead to a hypercontractile state of VSMCs and dedifferentiation to a proliferative and synthetic phenotype in both large and small arteries $(16,162)$. In larger conductive arteries, VSMCs primarily undergo hypertrophy, stiffening (144), and apoptosis $(33,147)$, and contribute to the increased intima-media thickness and arterial stiffness.

Vascular ECM remodeling during hypertension exerts effects on the functional and structural alterations in VSMCs. Several studies have shown that the mechanical properties of the extracellular environment, such as substrate stiffness, directly impact cell behaviors, including motility, proliferation, and differentiation. For example, an elevated substrate modulus increases VSMC contractility without inducing phenotype switching (157), whereas the increased nanoscale rigidity of collagen fibrils causes VSMCs to dedifferentiate into a proliferative phenotype (115). A recent study indicated that substrate stiffening induces a contractile-to-synthetic phenotypic transition in VSMCs, accompanied by downregulation of DNA methyltransferase 1 (DNMT1), which leads to the loss of specific SMC markers and the acquisition of osteogenic markers, thereby facilitating the phenotypic transition induced by matrix stiffening (176). Increased ECM stiffness mechanically activates Yes-associated protein (YAP) and WW domain-containing transcription regulator protein 1 (TAZ); these proteins translocate to the nucleus, where they interact with TEAD and regulate the expression of several genes, including connective tissue growth factor (CTGF) and collagens. Activation of YAP/TAZ signaling increases VSMC proliferation and migration $(66,131)$. Increased ECM stiffness may also activate matrix binding receptor integrins and the subsequent intracellular signaling pathways, including phosphoinositide 3-kinase (PI3K)/protein kinase $\mathrm{B}$ (Akt), $\beta$-catenin, and RhoA/Rho-associated protein kinase (ROCK), which results in VSMC contraction, proliferation, and migration $(27,41,91,132)$ (Fig. 2).

Collagen not only determines vascular ECM stiffness but also affects VSMC biological characteristics under physiological and pathological conditions. VSMCs cultured on monomeric collagen I exhibit elevated expression of vascular 
Table 3. Phenotype of Human and Animals with Gene Mutation or Modification of Vascular Extracellular Matrix Component

\begin{tabular}{|c|c|c|c|c|c|}
\hline Gene & Species & $\begin{array}{l}\text { Mutation/ } \\
\text { modification }\end{array}$ & $B P$ & Phenotype & References \\
\hline \multirow[t]{3}{*}{ Eln } & Human & $\begin{array}{l}\text { Loss of function } \\
\text { mutation }\end{array}$ & Hypertension & SVAS, increased arterial stiffness & (98) \\
\hline & Mouse & $\operatorname{Eln}^{-1-}$ & Not detected & $\begin{array}{l}\text { Died within a few days after birth, } \\
\text { obstructive aortic occlusion }\end{array}$ & (97) \\
\hline & Mouse & $\operatorname{Eln}^{+/-}$ & Hypertension & $\begin{array}{l}\text { Increased arterial stiffness, mild } \\
\text { cardiac hypertrophy }\end{array}$ & $(50,165)$ \\
\hline \multirow[t]{3}{*}{$\begin{array}{l}\text { Fibulin-4 } \\
\quad(\text { Fbln } 4)\end{array}$} & Mouse & $F b \ln 4^{-1-}$ & Not detected & $\begin{array}{l}\text { Died at birth, ascending aortic } \\
\text { aneurysm, increased artery } \\
\text { stiffness }\end{array}$ & (71) \\
\hline & Mouse & $F b \ln 4^{\mathrm{SMKO}}$ & Not detected & $\begin{array}{l}\text { Ascending aortic aneurysm and } \\
\text { increased artery stiffness }\end{array}$ & (71) \\
\hline & Mouse & $F b \ln 4^{\mathrm{E} 57 \mathrm{~K} / \mathrm{E} 57 \mathrm{~K}}$ & Hypertension & $\begin{array}{l}\text { Elastic fiber fragmentation and } \\
\text { increased stiffness in large artery }\end{array}$ & $(61,73)$ \\
\hline $\begin{array}{l}\text { Fibulin-5 } \\
\quad \text { (Fbln5) }\end{array}$ & Mouse & $F b \ln 5^{-1-}$ & Not detected & $\begin{array}{l}\text { Increased artery stiffness, } \\
\text { fragmented elastic fibers, } \\
\text { decreased artery contractility }\end{array}$ & (181) \\
\hline \multirow[t]{2}{*}{ Fbn1 } & Human & Mutation & Normal & $\begin{array}{l}\text { Marfan syndrome, thoracic aortic } \\
\text { aneurysm, and dissection }\end{array}$ & (37) \\
\hline & Mouse & $F b n 1^{\mathrm{mgR} / \mathrm{mgR}}$ & $\begin{array}{l}\text { Increased pulse } \\
\text { pressure }\end{array}$ & $\begin{array}{l}\text { Fragmented arterial elastic fibers, } \\
\text { increased aortic stiffness }\end{array}$ & (112) \\
\hline Emilinl & Mouse & Emilin1 $1^{-1}$ & Hypertension & $\begin{array}{l}\text { Increased peripheral vascular resis- } \\
\text { tance, activated TGF- } \beta \text { signaling }\end{array}$ & (186) \\
\hline $\begin{array}{l}\text { CollA1/ } \\
\text { CollA2 }\end{array}$ & Human & Mutation & Not detected & $\begin{array}{l}\text { Aortic dilatation, dissection and } \\
\text { rupture, Ehler-Danlos syndrome }\end{array}$ & (21) \\
\hline CollA1 & Mouse & Mutation & Not detected & Aortic dissection & (138) \\
\hline$T S P-1$ & Mouse & $T s p-1^{-l-}$ & $\begin{array}{l}\text { Increased central } \\
\text { diastolic and mean } \\
\text { arterial BP }\end{array}$ & $\begin{array}{l}\text { Activity-associated increase in heart } \\
\text { rate, a constant decrease in pulse } \\
\text { pressure, attenuated hypertensive } \\
\text { response to epinephrine }\end{array}$ & $(77)$ \\
\hline$T S P-4$ & Mouse & $T s p-4^{-1-}$ & $\begin{array}{l}\text { A similar BP increase } \\
\text { as WT mice after } \\
\text { Ang II infusion }\end{array}$ & $\begin{array}{l}\text { Alleviated dysfunction of } \\
\text { endothelial-dependent relaxation }\end{array}$ & (129) \\
\hline COMP & Mouse & Сотр ${ }^{-l-}$ & Normal & Increased PWV and artery stiffness & (169) \\
\hline$O P N$ & Mouse & $\mathrm{Opn}^{-1}$ & $\begin{array}{l}\text { A similar BP increase } \\
\text { as control mice after } \\
\text { Ano II infusion }\end{array}$ & $\begin{array}{l}\text { Decreased MMP-2 and MMP-9 } \\
\text { activity }\end{array}$ & (17) \\
\hline$M M P-2$ & Mouse & $M m p 2^{-/-}$ & $\begin{array}{l}\text { A similar BP increase } \\
\text { as WT mice after } \\
\text { Ang II infusion }\end{array}$ & $\begin{array}{l}\text { Alleviation of Ang II-induced } \\
\text { endothelial dysfunction and } \\
\text { vascular stiffness }\end{array}$ & (6) \\
\hline$M M P-9$ & Mouse & $M m p 9^{-/-}$ & Elevated pulse pressure & $\begin{array}{l}\text { Less collagen I breakdown } \\
\text { products, reduced artery } \\
\text { compliance, increased SBP in } \\
\text { response to Ang II }\end{array}$ & (52) \\
\hline$M M P-7$ & Mouse & $M m p 7^{-/-}$ & $\begin{array}{l}\text { Reduced BP in } \\
\text { NE-induced } \\
\text { hypertension }\end{array}$ & $\begin{array}{l}\text { Attenuation of } \alpha 1 \text {-adrenergic } \\
\text { contractile responses in isolated } \\
\text { small mesenteric arteries }\end{array}$ & $(171)$ \\
\hline$T I M P-3$ & Mouse & $\operatorname{Timp}^{-/-}$ & $\begin{array}{l}\text { Decreased BP after } \\
\text { L-NAME } \\
\text { administration }\end{array}$ & $\begin{array}{l}\text { Attenuated thickness and fibrosis } \\
\text { in vascular walls }\end{array}$ & (68) \\
\hline Cathepsin A & Mouse & Cathepsin $A^{-/-}$ & Hypertension & $\begin{array}{l}\text { Abnormal elastic fiber formation } \\
\text { and a reduced degradation rate } \\
\text { of ET-1 }\end{array}$ & (146) \\
\hline ADAMTS-16 & Rat & $\begin{array}{l}\text { Loss of function } \\
\text { mutation }\end{array}$ & $\begin{array}{l}\text { Decreased BP in Dahl } \\
\text { salt-sensitive rat }\end{array}$ & $\begin{array}{l}\text { Decreased PWV and media } \\
\text { thickness }\end{array}$ & (58) \\
\hline ADAMTS-18 & Mouse & Adamts $18^{-1-}$ & Hypertension & Early metabolic syndrome & (190) \\
\hline$A D A M-17$ & Mouse & Adam $17^{\text {SMKO }}$ & $\begin{array}{l}\text { Transiently decreased } \\
\text { BP in Ang II-induced } \\
\text { hypertension }\end{array}$ & $\begin{array}{l}\text { Alleviated cardiac hypertrophy and } \\
\text { fibrosis }\end{array}$ & (148) \\
\hline
\end{tabular}

ADAMTS, a disintegrin and metalloproteinase with thrombospondin motif; Eln, elastin; ET-1, endothelin-1; Fbln, fibulin; Fbn, fibrillin; NE, norepinephrine; SBP, systolic blood pressure; SMKO, smooth muscle-specific knockout; SVAS, supravalvular aortic stenosis; TGF- $\beta$, transforming growth factor- $\beta$; TIMP, tissue inhibitor of metalloproteinase; WT, wild type. 
FIG. 2. Elevated ECM stiffness and vascular cell behaviors. Increased ECM stiffness activates YAP/TAZ signaling and integrins, which results in VSMC contraction, proliferation, and migration. YAP, Yes-associated protein. Color images are available online.

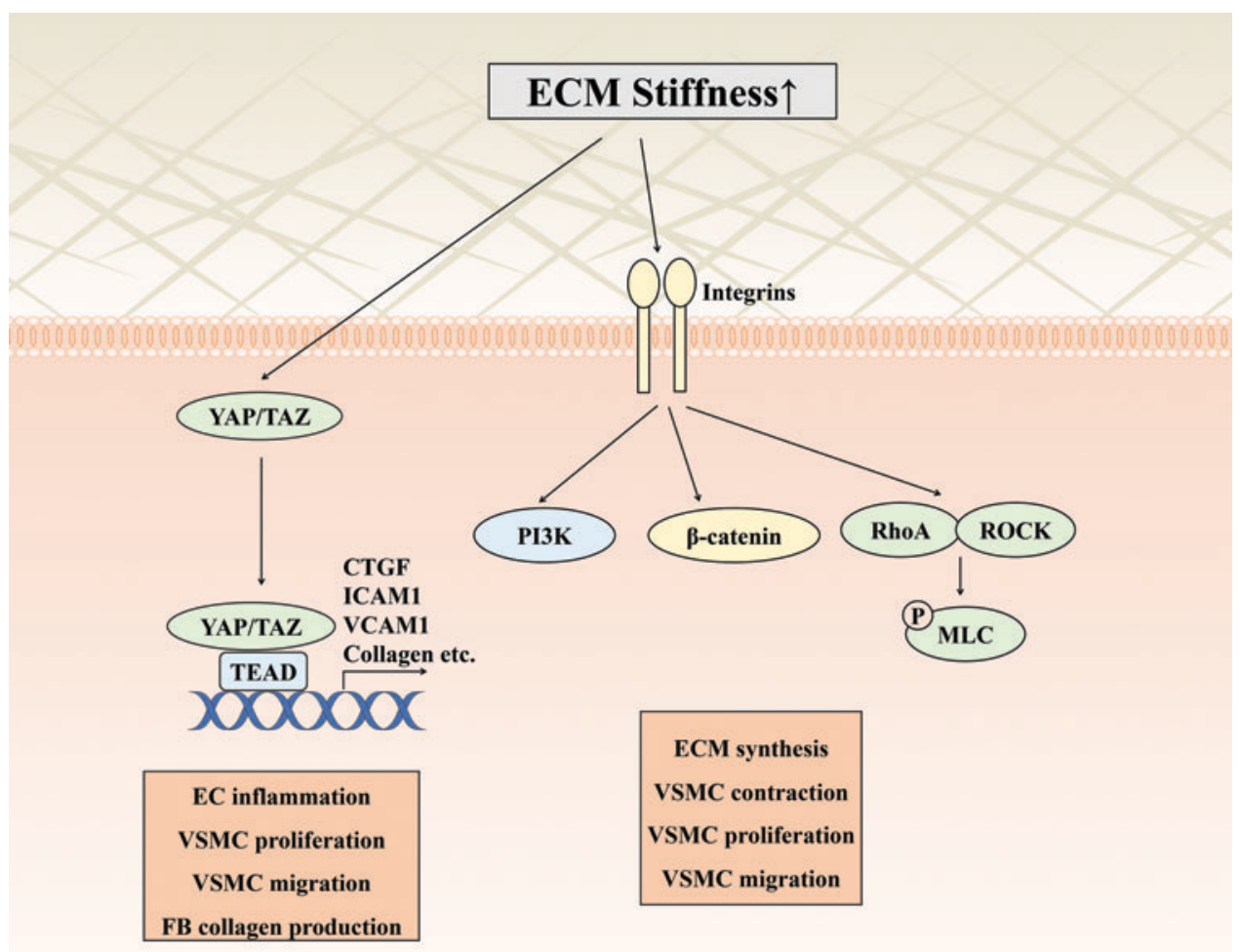

cell adhesion molecule-1 (VCAM-1) and undergo osteo-/ chondrogenic phenotypic switching (128, 173), whereas polymerized type I collagen inhibits VSMC migration and proliferation via upregulating p27Kip1 and p21Cip1 (89). Another study further revealed that the degradation of polymerized collagen I by MMPs induces the release of collagen fragments that trigger SMC apoptosis through the activation of calpain and the subsequent proteolysis of antiapoptotic X-chromosome-linked inhibitor of apoptosis (xIAP) (104).

Elastin governs VSMC proliferation, acts as a positive regulator of VSMC maturation, and modulates the VSMC phenotype toward a contractile state (140). A direct relationship between increased VSMC proliferation and decreased elastin levels has been reported in cultured VSMCs from supravalvular aortic stenosis and Williams-Beuren syndrome patients and elastin deficiency murine models (97, 136, 163). Li et al. found that loss of elastin leads to activation of mammalian target of rapamycin (mTOR) signaling, and that rapamycin inhibits VSMC proliferation and aortic obstruction in elastin-deficient mice (99). Supplementation of elastin-deficient VSMCs with tropoelastin increases the level of active RhoA and inhibits proliferation in a dosedependent manner (85). The mechanism underlying the elastin-VSMC interaction may include interaction of the elastin C-terminal RKRK motif with integrin $\alpha_{\mathrm{v}} \beta_{3}$ and the tropoelastin VGVAPG domain with G-protein coupled receptors (GPCRs) (47). In addition, elastin fibers sequester growth factors, such as latent TGF- $\beta$, and degradation of elastin fibers during hypertension releases fibrillin-1 from binding with latent TGF- $\beta$, thus enhancing the synthesis of collagen I, II, III, fibronectin, and CTGF via the activation of its downstream signaling effector Smad in VSMCs (Fig. 3). Recent studies have also elaborated on the roles of the elas- tin degradation products, named elastin-derived peptides (EDPs), in hypertension. EDPs containing a GxxPG motif stabilize the type VIII $\beta$-turn conformation and exhibit bioactivity (13). EDPs bind to several cell surface receptors, including galectin-3 and integrin $\alpha_{\mathrm{v}} \beta_{3}$ and $\alpha_{\mathrm{v}} \beta_{5}$, but the most important signaling mediator is the elastin receptor complex (ERC), which consists of elastin binding protein (EBP), protective protein/cathepsin A (PPCA), and neuraminidase-1 (Neu-1) (8). EDPs bind to the ERC, promote VSMC proliferation through $\mathrm{Gi}$ activation, and amplify the elastin fragmentation effect $(44,121)$ (Fig. 3). Increased advanced glycation end products (AGEs) have been reported to promote proliferation of VSMCs via a reduction in cathepsin D and upregulation of $\mathrm{Bcl} 2$-associated athanogene 3 (BAG3) $(96,110)$. Proteases involved in ECM degradation also regulate VSMC proliferation and migration. Active MMP-2 cleaves calponin-1 in VSMCs to switch their phenotype to a dedifferentiated state and increases the phosphorylation of ERK1/2 to induce cell proliferation $(26,108)$.

The adhesive glycoprotein fibronectin builds connections between the ECM and VSMCs via $\alpha_{5} \beta_{1}$ and $\alpha_{v} \beta_{3}$ integrin receptors. VSMCs cultured on mechanical gradients coated with fibronectin undergo durotaxis toward stiffer regions (63). Fibronectin-splice variant containing extra domain A (Fn-EDA) drives integrin- and Toll-like receptor 4 (TLR4)dependent VSMC proliferation and migration through activation of the focal adhesion kinase (FAK)/Src and Akt1/ mTOR signaling pathways (81). Heparin, a major glycosaminoglycan component in the vascular ECM, maintains the contractile SMC phenotype and inhibits VSMC proliferation through blocking G1-to-S-phase transition via p27kip1mediated inhibition of cyclin-dependent kinase 2 activity (49). Perlecan, a heparan sulfate PG expressed mainly in 


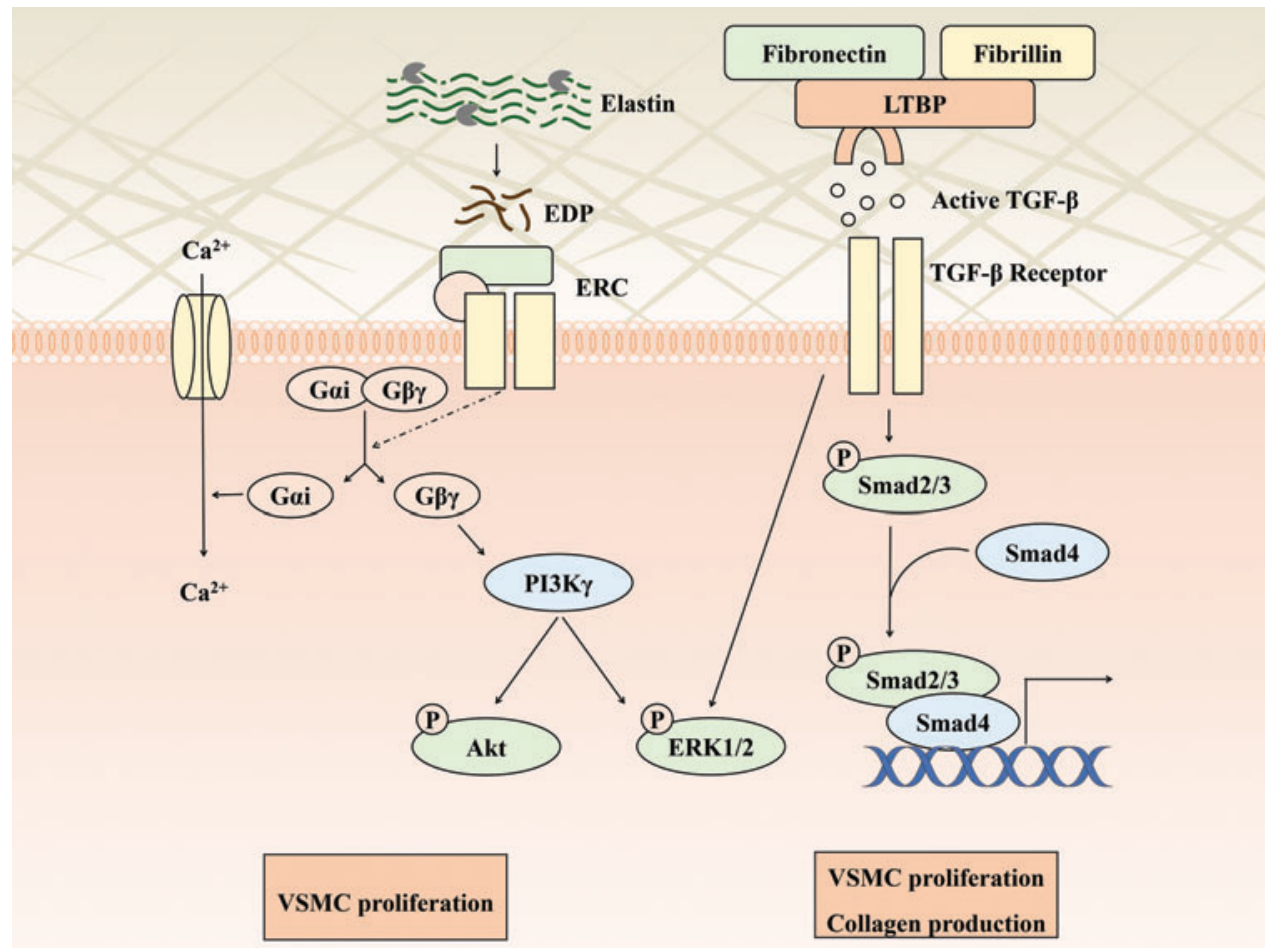

FIG. 3. Elastin degradation and vascular cell behaviors. Degradation of elastin exposes VSMC to bioactive molecules including TGF- $\beta$ and EDPs, contributing to the increased VSMC proliferation and ECM synthesis. EDP, elastin-derived peptides; ERC, elastin receptor complex; TGF- $\beta$, transforming growth factor- $\beta$. Color images are available online.
BMs, inhibits VSMC proliferation by sequestering fibroblast growth factor-2 (FGF-2) (106), whereas versican, a chondroitin sulfate PG, stimulates VSMC proliferation (72). TSP-1 induces VSMC migration and proliferation by modulating the function of miRNA-21, and enhances VSMC phenotypic switching $(141,154)$. OPN stimulates VSMC proliferation via epidermal growth factor receptor (EGFR)mediated activation of the AP- 1 and $\mathrm{C} / \mathrm{EBP} \beta$ pathways (94). Cyr61/CTGF/NOV (CCN) proteins are a family of secreted matricellular proteins that control cell adhesion, growth, and differentiation. CCN1 stimulates VSMC adhesion and proliferation through interaction with $\alpha_{6} \beta_{1}$ integrin and heparin sulfate PGs (1), and CCN4 enhances the adhesion and migration of VSMCs via binding to integrin $\alpha_{5} \beta_{1}$ (105).

\section{ECM remodeling, inflammation, and oxidative stress}

Increased evidence has identified inflammation as a key mechanism underlying vascular cell dysfunction and arterial damage in hypertension (60). Studies have demonstrated increased plasma levels of C-reactive protein (CRP), interleukin (IL)-6, IL-1 $\beta$, and tumor necrosis factor- $\alpha$ (TNF- $\alpha$ ) in hypertensive patients (7). Hypertension is associated with the infiltration of immune cells and the release of proinflammatory cytokines by activated $\mathrm{T}$ cells in vascular walls, which contribute to vascular remodeling (59). Xu et al. found collagen deposition and inflammatory cell infiltration at the early stage of hypertension in a two-kidney, one-clip rat hypertension model (179). During hypertension, MMPs degrade the ECM to facilitate the migration and recruitment of inflammatory cells and cleave cell surface receptors and other non-ECM molecules to mediate the adhesion, proliferation, and apoptosis of cells in the vessel wall; these events are involved in the inflammatory process (170). Frolova et al. revealed that TSP-4 promotes the adhesion and migration of macrophages by activating ECs and interacting with macrophages in a $\beta_{2}$ and $\beta_{3}$ integrin-dependent manner (55). An in vitro study revealed that TNC enhances macrophage migration and activates the NF- $\kappa$ B-related proinflammatory pathway via integrin $\alpha_{\mathrm{V}} \beta_{3}$ (149). The $\mathrm{N}$-terminal OPN fragment, a product of OPN proteolysis by thrombin and MMPs, correlates with increased inflammation severity in carotid plaques in patients with hypertension (2). The involvement of OPN in hypertension-related inflammation and remodeling is further evidenced by the finding that the early macrophage infiltration into the arterial wall in response to hypertension is blunted in OPN-deficient mice (22).

Oxidative stress refers to the excessive generation of reactive oxygen species (ROS), and its role in the pathogenesis of hypertension has been elucidated (139). Elevated expression and activity of LOX during hypertension have also been reported to incidentally enhance oxidative stress (113). TSP1 binding to CD47 leads to the phosphorylation of NADPH oxidase subunit $\mathrm{p} 47$ and the subsequent activation of Nox1, thus triggering the generation of superoxide and the impairment of arterial vasodilatation (30). CCN1 induces mitochondrial production of ROS through binding to $\alpha_{\mathrm{v}} \beta_{5}$ and $\alpha_{6} \beta_{1}$ integrins and the heparin sulfate PG syndecan-4 during TNF- $\alpha$-induced apoptosis in fibroblasts (28). Periostin inhibits glucose-induced ROS production by upregulating heme oxygenase- 1 and preserving mitochondrial function in ECs (189). Although above evidence increasingly reveals the modulation of vascular ECM on ROS production, the interaction between ECM remodeling and oxidative stress in the pathogenesis of hypertension is still limited and needs to be further augmented. 


\section{Diagnostic and Therapeutic Relevance of the ECM in Hypertension}

\section{ECM alterations after antihypertensive treatment}

Although the mechanisms of traditional antihypertensive medications, including angiotensin receptor blockers (ARBs), angiotensin-converting enzyme inhibitors (ACEIs), calcium channel blockers (CCBs), beta blockers, diuretics, etc., are well clarified, their influence on vascular ECM remodeling is not fully understood. A series of studies revealed that treatment with ACEIs, ARBs, CCBs, and diuretics contributes to downregulation of MMP-2/9 in hypertension patients and rodent models (69). However, in some cases, plasma MMP-2 and MMP-9 levels are elevated by felodipine (CCB) and amlodipine (CCB) treatment, respectively (187, 188). Patients with essential hypertension who were treated with candesartan cilexetil (an ARB) show attenuated arterial stiffness, accompanied by a significant decrease in serum procollagen type III propeptide and an increase in serum MMP-3 levels (142). In addition, SHR treated with a combination of verapamil (CCB) and trandolapril (ACEI) showed a reduced collagen content, increased carotid artery fibronectin expression, and a significant increase in arterial distensibility (88). Notably, some ECM alterations are specific to certain treatments. For instance, serum TSP-1 levels in hypertensive patients are upregulated by treatment with perindopril (ACEI) but not other kinds of antihypertensive drugs, suggesting that TSP-1 could be a specific biomarker for ACEI efficacy $(18,19)$. Several nonclassical therapeutic strategies have also been used in preclinical studies. Cyclooxygenase (COX)-2 inhibitors, such as celecoxib or rofecoxib, showed protective effects in mice with Ang II-induced hypertension, and these effects were accompanied by reduced collagen deposition and an increase in the fenestrated area of the IEL (4). In addition, in SHR, upregulation of Fibulin-3 and MMP-2/9 is associated with hypertension and is inhibited by Xuezhikang, a traditional Chinese medicine extracted from red yeast rice (101). Treatment of brown Norway rats with the potassium channel openers minoxidil or diazoxide for 10 weeks elevated the elastic fiber content in the aortic media (150).

\section{Targeting ECM for hypertension prediction and therapy}

In a large multiethnic study, Duprez et al. found that the collagen biomarkers PIIINP and ICTP predicted the development of hypertension during a median time interval of $\sim 10$ years (45). Another study including 595 nonhypertensive Framingham Offspring Study participants demonstrated that increased serum concentrations of TIMP-1 and MMP-9 are associated with BP progression on follow-up (34). Studies on the role of ECM biomarkers in hypertension development and complications deserve more attention. Although current antihypertensive drugs are appropriately applied, their efficacy in some patients is not satisfactory. Thus, discovering new therapeutic strategies is of great importance. As shown in Table 3, altered ECM components could serve as pathogenic factors for vascular dysfunction and drivers of hypertension development or play an antihypertensive role, indicating that ECM proteins and proteases could be potential targets for antihypertensive treatment. Considering the complexity of the ECM, targeting a specific
ECM protein might be a biased and invalid approach. Thus, progress has been made toward ECM protease regulation in hypertension. In the $2 \mathrm{~K}-1 \mathrm{C}$ hypertensive rat model, treatment with doxycycline, a nonselective MMP inhibitor, ameliorates hypertension, reverses impaired vasorelaxation, and prevents alterations in the vascular structure (25). In addition, MMP inhibition by GM6001 could reduce type I collagen deposition, and increase elastin in intrarenal vessels and attenuate adverse renovascular remodeling in hypertensive Dahl/SS rats (135).

\section{Conclusions and Perspectives}

Although exploration of the pathological mechanisms underlying hypertension has profoundly progressed in recent decades, knowledge on the dynamic alterations in the vascular ECM remains limited. It is unclear whether vascular ECM remodeling is a cause or result of hypertension, but evidence from human and animal studies, as discussed in this review, suggests that vascular ECM remodeling leads to the development of hypertension. In this review, we hypothesize that ECM remodeling in the component profiles, mechanical properties, degradation processes, and degraded fragment production leads to subsequent vascular wall structural and functional remodeling and results in hypertension. In further research, the application of matridomic and degradomic approaches may provide evidence for the identification of diverse ECM components. A better understanding of vascular matrix biology and the intricate mechanisms underlying hypertension may provide new insights into the development of antihypertensive strategies.

\section{Funding Information}

This work was supported by funding from the National Natural Science Foundation of P.R. China (NSFC, 81921001 , 91839302, 81730010, and 31930056).

\section{References}

1. Abe JI and Yan C. CCN notch signaling in vascular smooth muscle cells good or bad? Arterioscler Thromb Vasc Biol 30: 667-668, 2010.

2. Agnihotri R, Crawford HC, Haro H, Matrisian LM, Havrda MC, and Liaw L. Osteopontin, a novel substrate for matrix metalloproteinase-3 (stromelysin-1) and matrix metalloproteinase-7 (matrilysin). J Biol Chem 276: 28261-28267, 2001.

3. Arribas SM, Hinek A, and González MC. Elastic fibres and vascular structure in hypertension. Pharmacol Ther 111: 771-791, 2006.

4. Avendano MS, Martinez-Revelles S, Aguado A, Simoes MR, Gonzalez-Amor M, Palacios R, Guillem-Llobat P, Vassallo DV, Vila L, Garcia-Puig J, Beltran LM, Alonso MJ, Cachofeiro MV, Salaices M, and Briones AM. Role of COX-2-derived PGE2 on vascular stiffness and function in hypertension. Br J Pharmacol 173: 1541-1555, 2016.

5. Barallobre-Barreiro J, Didangelos A, Schoendube FA, Drozdov I, Yin XK, Fernandez-Caggiano M, Willeit P, Puntmann VO, Aldama-Lopez G, Shah AM, Domenech $\mathrm{N}$, and Mayr M. Proteomics analysis of cardiac extracellular matrix remodeling in a porcine model of ischemia/ reperfusion injury. Circulation 125: 789-802, 2012. 
6. Barhoumi T, Fraulob-Aquino JC, Mian MOR, Ouerd S, Idris-Khodja N, Huo KG, Rehman A, Caillon A, DancoseGiambattisto B, Ebrahimian T, Lehoux S, Paradis P, and Schiffrin EL. Matrix metalloproteinase-2 knockout prevents angiotensin II-induced vascular injury. Cardiovasc Res 113: 1753-1762, 2017.

7. Bautista LE, Vera LM, Arenas IA, and Gamarra G. Independent association between inflammatory markers (C-reactive protein, interleukin-6, and TNF-alpha) and essential hypertension. J Hum Hypertens 19: 149-154, 2005.

8. Bennasroune A, Romier-Crouzet B, Blaise S, Laffargue M, Efremov RG, Martiny L, Maurice P, and Duca L. Elastic fibers and elastin receptor complex: neuraminidase-1 takes the center stage. Matrix Biol 84: 57-67, 2019.

9. Bezie Y, Lamaziere JM, Laurent S, Challande P, Cunha RS, Bonnet J, and Lacolley P. Fibronectin expression and aortic wall elastic modulus in spontaneously hypertensive rats. Arterioscler Thromb Vasc Biol 18: 1027-1034, 1998.

10. Bouissou C, Lacolley P, Dabire H, Safar ME, Gabella G, Duchatelle V, Challande P, and Bezie Y. Increased stiffness and cell-matrix interactions of abdominal aorta in two experimental nonhypertensive models: longtermchemically sympathectomized and sinoaortic denervated rats. J Hypertens 32: 652-658, 2014.

11. Bouvet C, Gilbert LA, Girardot D, deBlois D, and Moreau P. Different involvement of extracellular matrix components in small and large arteries during chronic NO synthase inhibition. Hypertension 45: 432-437, 2005.

12. Bowman TS, Gaziano JM, Buring JE, and Sesso HD. A prospective study of cigarette smoking and risk of incident hypertension in women. J Am Coll Cardiol 50: 20852092, 2007.

13. Brassart B, Fuchs P, Huet E, Alix AJP, Wallach J, Tamburro AM, Delacoux F, Haye B, Emonard H, Hornebeck W, and Debelle L. Conformational dependence of collagenase (matrix metalloproteinase-1) upregulation by elastin peptides in cultured fibroblasts. J Biol Chem 276: 5222-5227, 2001.

14. Briones AM, Arribas SM, and Salaices M. Role of extracellular matrix in vascular remodeling of hypertension. Curr Opin Nephrol Hypertens 19: 187-194, 2010.

15. Briones AM, Xavier FE, Arribas SM, Gonzalez MC, Rossoni LV, Alonso MJ, and Salaices M. Alterations in structure and mechanics of resistance arteries from ouabain-induced hypertensive rats. Am J Physiol Heart Circ Physiol 291: H193-H201, 2006.

16. Brown IAM, Diederich L, Good ME, DeLalio LJ, Murphy SA, Cortese-Krott MM, Hall JL, Le TH, and Isakson BE. Vascular smooth muscle remodeling in conductive and resistance arteries in hypertension. Arterioscler Thromb Vasc Biol 38: 1969-1985, 2018.

17. Bruemmer D, Collins AR, Noh G, Wang W, Territo M, Arias-Magallona S, Fishbein MC, Blaschke F, Kintscher U, Graf K, Law RE, and Hsueh WA. Angiotensin IIaccelerated atherosclerosis and aneurysm formation is attenuated in osteopontin-deficient mice. J Clin Invest 112: 1318-1331, 2003.

18. Buda V, Andor M, Cristescu C, Tomescu MC, Muntean DM, Baibata DE, Bordejevic DA, Danciu C, Dalleur O, Coricovac D, Crainiceanu Z, Tudor A, Ledeti I, and Petrescu L. Thrombospondin-1 serum levels in hypertensive patients with endothelial dysfunction after one year of treatment with perindopril. Drug Des Devel Ther 13: 3515-3526, 2019.

19. Buda V, Andor M, Petrescu L, Cristescu C, Baibata D, Voicu M, Munteanu M, Citu I, Muntean C, Cretu O, and Tomescu M. Perindopril induces TSP-1 expression in hypertensive patients with endothelial dysfunction in chronic treatment. Int J Mol Sci 18: 348-362, 2017.

20. This reference has been deleted.

21. Byers PH, Belmont J, Black J, De Backer J, Frank M, Jeunemaitre X, Johnson D, Pepin M, Robert L, Sanders L, and Wheeldon N. Diagnosis, natural history, and management in vascular Ehlers-Danlos syndrome. Am J Med Genet C Semin Med Genet 175: 40-47, 2017.

22. Caesar C, Lyle AN, Joseph G, Weiss D, Alameddine FMF, Lassègue B, Griendling KK, and Taylor WR. Cyclic strain and hypertension increase osteopontin expression in the aorta. Cell Mol Bioeng 10: 144-152, 2016.

23. Carty DM, Schiffer E, and Delles C. Proteomics in hypertension. J Hum Hypertens 27: 211-216, 2013.

24. Castro CM, Cruzado MC, Miatello RM, and Risler NR. Proteoglycan production by vascular smooth muscle cells from resistance arteries of hypertensive rats. Hypertension 34: 893-896, 1999.

25. Castro MA, Rizzi E, Figueiredo-Lopes L, Fernandes K, Bendhack LA, Pitol DL, Gerlach RE, and Tanus-Santos JE. Metalloproteinase inhibition ameliorates hypertension and prevents vascular dysfunction and remodeling in renovascular hypertensive rats. Atherosclerosis 198: 320331, 2008.

26. Castro MM, Cena J, Cho WJ, Walsh MP, and Schulz R. Matrix metalloproteinase-2 proteolysis of calponin-1 contributes to vascular hypocontractility in endotoxemic rats. Arterioscler Thromb Vasc Biol 32: 662-668, 2012.

27. Chaterji S, Kim P, Choe SH, Tsui JH, Lam CH, Ho DS, Baker AB, and Kim D. Synergistic effects of matrix nanotopography and stiffness on vascular smooth muscle cell function. Tissue Eng Part A 20: 2115-2126, 2014

28. Chen CC, Young JL, Monzon RI, Chen N, Todorovic V, and Lau LF. Cytotoxicity of TNF alpha is regulated by integrin-mediated matrix signaling. EMBO $J$ 26: 12571267, 2007.

29. Chow MJ, Turcotte R, Lin CP, and Zhang Y. Arterial extracellular matrix: a mechanobiological study of the contributions and interactions of elastin and collagen. Biophys J 106: 2684-2692, 2014.

30. Csanyi G, Yao M, Rodriguez AI, Al Ghouleh I, SharifiSanjani M, Frazziano G, Huang X, Kelley EE, Isenberg JS, and Pagano PJ. Thrombospondin-1 regulates blood flow via CD47 receptor-mediated activation of NADPH oxidase 1. Arterioscler Thromb Vasc Biol 32: 2966-2973, 2012.

31. DeLeon KY, Bras LED, Lange RA, and Lindsey ML. Extracellular matrix proteomics in cardiac ischemia/ reperfusion the search is on. Circulation 125: 746-748, 2012.

32. Delles C, Carrick E, Graham D, and Nicklin SA. Utilizing proteomics to understand and define hypertension: where are we and where do we go? Expert Rev Proteomics 15: 581-592, 2018.

33. Devlin AM, Clark JS, Reid JL, and Dominiczak AF. DNA synthesis and apoptosis in smooth muscle cells from a model of genetic hypertension. Hypertension 36: 110115, 2000. 
34. Dhingra R, Pencina MJ, Schrader P, Wang TJ, Levy D, Pencina K, Siwik DA, Colucci WS, Benjamin EJ, and Vasan RS. Relations of matrix remodeling biomarkers to blood pressure progression and incidence of hypertension in the community. Circulation 119: 1101-1107, 2009.

35. Didangelos A, Yin X, Mandal K, Baumert M, Jahangiri $\mathrm{M}$, and Mayr M. Proteomics characterization of extracellular space components in the human aorta. Mol Cell Proteomics 9: 2048-2062, 2010.

36. Didangelos A, Yin XK, Saje A, Smith A, Xu QB, Jahangiri M, and Mayr M. Extracellular matrix composition and remodelling in human abdominal aortic aneurysms: a proteomics approach. Vasc Pharmacol 56: 343, 2012.

37. Dietz HC and Pyeritz RE. Mutations in the human gene for fibrillin-1 (FBN1) in the Marfan syndrome and related disorders. Hum Mol Genet 4 Spec No: 1799-1809, 1995.

38. Diez $\mathbf{J}$ and Hernandez M. Is the extracellular degradation of collagen type I fibers depressed in spontaneously hypertensive rats with myocardial fibrosis? Circulation 94: 2998, 1996.

39. Diez J, Laviades C, Mayor G, Gil MJ, and Monreal I. Increased serum concentrations of procollagen peptides in essential-hypertension-relation to cardiac alterations. Circulation 91: 1450-1456, 1995.

40. Doucet A, Butler GS, Rodriguez D, Prudova A, and Overall CM. Metadegradomics toward in vivo quantitative degradomics of proteolytic post-translational modifications of the cancer proteome. Mol Cell Proteomics 7: 1925-1951, 2008.

41. Du J, Zu Y, Li J, Du SY, Xu YP, Zhang L, Jiang L, Wang Z, Chien S, and Yang C. Extracellular matrix stiffness dictates Wnt expression through integrin pathway. Sci Rep 6: 20395-20406, 2016.

42. Du Y-H, Guan Y-Y, Alp NJ, Channon KM, and Chen AF. Endothelium-specific GTP cyclohydrolase I overexpression attenuates blood pressure progression in salt-sensitive low-renin hypertension. Circulation 117: 1045-1054, 2008.

43. Duca L, Blaise S, Romier B, Laffargue M, Gayral S, El Btaouri H, Kawecki C, Guillot A, Martiny L, Debelle L, and Maurice P. Matrix ageing and vascular impacts: focus on elastin fragmentation. Cardiovasc Res 110: 298308, 2016.

44. Duca L, Lambert E, Debret R, Rothhut B, Blanchevoye C, Delacoux F, Hornebeck W, Martiny L, and Debelle L. Elastin peptides activate extracellular signal-regulated kinase $1 / 2$ via a Ras-independent mechanism requiring both p110gamma/Raf-1 and protein kinase A/B-Raf signaling in human skin fibroblasts. Mol Pharmacol 67: 1315-1324, 2005.

45. Duprez DA, Gross MD, Ix JH, Kizer JR, Tracy RP, Shea $\mathrm{S}$, and Jacobs DR, Jr. Collagen biomarkers predict new onset of hypertension in normotensive participants: the Multi-Ethnic Study of Atherosclerosis. J Hypertens 36: 2245-2250, 2018.

46. Eberson LS, Sanchez PA, Majeed BA, Tawinwung S, Secomb TW, and Larson DF. Effect of lysyl oxidase inhibition on angiotensin II-induced arterial hypertension, remodeling, and stiffness. PLoS One 10: e0124013, 2015.

47. Ellis MW, Luo J, and Qyang Y. Modeling elastinassociated vasculopathy with patient induced pluripotent stem cells and tissue engineering. Cell Mol Life Sci 76: 893-901, 2019.
48. Ergul A, Portik-Dobos V, Hutchinson J, Franco J, and Anstadt MP. Downregulation of vascular matrix metalloproteinase inducer and activator proteins in hypertensive patients. Am J Hypertens 17: 775-782, 2004.

49. Fasciano S, Patel RC, Handy I, and Patel CV. Regulation of vascular smooth muscle proliferation by heparin: inhibition of cyclin-dependent kinase 2 activity by p27(kip1). J Biol Chem 280: 15682-15689, 2005.

50. Faury G, Pezet M, Knutsen RH, Boyle WA, Heximer SP, McLean SE, Minkes RK, Blumer KJ, Kovacs A, Kelly DP, Li DY, Starcher B, and Mecham RP. Developmental adaptation of the mouse cardiovascular system to elastin haploinsufficiency. J Clin Invest 112: 1419-1428, 2003.

51. Feng H, Li H, Zhang D, Zhao Y, Jiang N, Zhao X, Zhang YU, Tan J, Fang WEN, Zhang Y, and Liu WEI. Aortic wall proteomic analysis in spontaneously hypertensive rats with a blood pressure decrease induced by 6-week load-free swimming. Biomed Rep 3: 681-686, 2015.

52. Flamant M, Placier S, Dubroca C, Esposito B, Lopes I, Chatziantoniou C, Tedgui A, Dussaule JC, and Lehoux S. Role of matrix metalloproteinases in early hypertensive vascular remodeling. Hypertension 50: 212-218, 2007.

53. Franklin SS, Gustin Wt, Wong ND, Larson MG, Weber MA, Kannel WB, and Levy D. Hemodynamic patterns of age-related changes in blood pressure. The Framingham Heart Study. Circulation 96: 308-315, 1997.

54. Franz M, Jung C, Lauten A, Figulla HR, and Berndt A. Tenascin-C in cardiovascular remodeling: potential impact for diagnosis, prognosis estimation and targeted therapy. Cell Adh Migr 9: 90-95, 2015.

55. Frolova EG, Pluskota E, Krukovets I, Burke T, Drumm C, Smith JD, Blech L, Febbraio M, Bornstein P, Plow EF, and Stenina OI. Thrombospondin-4 regulates vascular inflammation and atherogenesis. Circ Res 107: 1313$1325,2010$.

56. Giannakos E, Vardali E, Bartekova M, Fogarassyova M, Barancik M, and Radosinska J. Changes in activities of circulating MMP-2 and MMP-9 in patients suffering from heart failure in relation to gender, hypertension and treatment: a cross-sectional study. Physiol Res 65(Suppl 1): S149-S152, 2016.

57. Gildner CD, Lerner AL, and Hocking DC. Fibronectin matrix polymerization increases tensile strength of model tissue. Am J Physiol Heart Circ Physiol 287: H46-H53, 2004.

58. Gopalakrishnan K, Kumarasamy S, Abdul-Majeed S, Kalinoski AL, Morgan EE, Gohara AF, Nauli SM, Filipiak WE, Saunders TL, and Joe B. Targeted disruption of Adamts16 gene in a rat genetic model of hypertension. Proc Natl Acad Sci U S A 109: 20555-20559, 2012.

59. Guzik TJ, Hoch NE, Brown KA, McCann LA, Rahman A, Dikalov S, Goronzy J, Weyand C, and Harrison DG. Role of the $\mathrm{T}$ cell in the genesis of angiotensin II-induced hypertension and vascular dysfunction. J Exp Med 204: 2449-2460, 2007.

60. Guzik TJ and Touyz RM. Oxidative stress, inflammation, and vascular aging in hypertension. Hypertension 70: 660-667, 2017.

61. Halabi CM, Broekelmann TJ, Lin M, Lee VS, Chu ML, and Mecham RP. Fibulin-4 is essential for maintaining arterial wall integrity in conduit but not muscular arteries. Sci Adv 3: e1602532, 2017. 
62. Halper J. Basic components of vascular connective tissue and extracellular matrix. Adv Pharmacol 81: 95-127, 2018.

63. Hartman CD, Isenberg BC, Chua SG, and Wong JY. Vascular smooth muscle cell durotaxis depends on extracellular matrix composition. Proc Natl Acad Sci U S A 113: 11190-11195, 2016.

64. Harvey A, Montezano AC, Lopes RA, Rios F, and Touyz RM. Vascular fibrosis in aging and hypertension: molecular mechanisms and clinical implications. Can J Cardiol 32: 659-668, 2016.

65. Hays TT, Ma B, Zhou N, Stoll S, Pearce WJ, and Qiu H. Vascular smooth muscle cells direct extracellular dysregulation in aortic stiffening of hypertensive rats. Aging Cell 17: e12748, 2018.

66. He JL, Bao QK, Yan M, Liang J, Zhu Y, Wang CJ, and Ai D. The role of Hippo/Yes-associated protein signalling in vascular remodelling associated with cardiovascular disease. Br J Pharmacol 175: 1354-1361, 2018.

67. Hielscher A, Ellis K, Qiu C, Porterfield J, and Gerecht S. Fibronectin deposition participates in extracellular matrix assembly and vascular morphogenesis. PLoS One 11: e0147600, 2016.

68. Higuchi M, Yasuda O, Kawamoto H, Yotsui T, Baba Y, Ozaki T, Maeda N, Fukuo K, Rakugi H, and Ogihara T. Tissue inhibitor of metalloproteinase-3 deficiency inhibits blood pressure elevation and myocardial microvascular remodeling induced by chronic administration of $\mathrm{N}$ omega-nitro-L-arginine methyl ester in mice. Hypertens Res 30: 563-571, 2007.

69. Hopps E, Lo Presti R, and Caimi G. Matrix metalloproteases in arterial hypertension and their trend after antihypertensive treatment. Kidney Blood Press $R$ 42: 347-357, 2017.

70. Hua Y and Nair S. Proteases in cardiometabolic diseases: pathophysiology, molecular mechanisms and clinical applications. Biochim Biophys Acta 1852: 195-208, 2015.

71. Huang J, Davis EC, Chapman SL, Budatha M, Marmorstein LY, Word RA, and Yanagisawa H. Fibulin-4 deficiency results in ascending aortic aneurysms: a potential link between abnormal smooth muscle cell phenotype and aneurysm progression. Circ Res 106: 583$592,2010$.

72. Huang R, Merrilees MJ, Braun K, Beaumont B, Lemire J, Clowes AW, Hinek A, and Wight TN. Inhibition of versican synthesis by antisense alters smooth muscle cell phenotype and induces elastic fiber formation in vitro and in neointima after vessel injury. Circ Res 98: 370-377, 2006.

73. Igoucheva O, Alexeev V, Halabi CM, Adams SM, Stoilov I, Sasaki T, Arita M, Donahue A, Mecham RP, Birk DE, and Chu ML. Fibulin-4 E57K knock-in mice recapitulate cutaneous, vascular and skeletal defects of recessive cutis laxa $1 \mathrm{~B}$ with both elastic fiber and collagen fibril abnormalities. J Biol Chem 290: 21443-21459, 2015.

74. Imanaka-Yoshida K, Yoshida T, and Miyagawa-Tomita S. Tenascin- $\mathrm{C}$ in development and disease of blood vessels. Anat Rec 297: 1747-1757, 2014.

75. Intengan HD, Deng LY, Li JS, and Schiffrin EL. Mechanics and composition of human subcutaneous resistance arteries in essential hypertension. Hypertension 33: 569-574, 1999.

76. Intengan HD and Schiffrin EL. Collagen degradation is diminished in mesenteric arteries of spontaneously hy- pertensive rats after hypertension is established. Hypertension 34: 329-329, 1999.

77. Isenberg JS, Qin Y, Maxhimer JB, Sipes JM, Despres D, Schnermann J, Frazier WA, and Roberts DD. Thrombospondin-1 and CD47 regulate blood pressure and cardiac responses to vasoactive stress. Matrix Biol 28: 110-119, 2009.

78. Ito H, Kwan CY, and Daniel EE. Elastin and elastase-like enzyme change in aorta of rat with malignant hypertension. Exp Mol Pathol 47: 26-36, 1987.

79. Iwatsuki K, Cardinale GJ, Spector S, and Udenfriend S. Reduction of blood-pressure and vascular collagen in hypertensive rats by beta-aminopropionitrile. Proc Natl Acad Sci U S A 74: 360-362, 1977.

80. Jacob MP. Extracellular matrix remodeling and matrix metalloproteinases in the vascular wall during aging and in pathological conditions. Biomed Pharmacother 57: 195-202, 2003.

81. Jain M, Dhanesha N, Doddapattar P, Chorawala MR, Nayak MK, Cornelissen A, Guo L, Finn AV, Lentz SR, and Chauhan AK. Smooth muscle cell-specific fibronectinEDA mediates phenotypic switching and neointimal hyperplasia. J Clin Invest 130: 295-314, 2020.

82. Jiang MQ and Cai JJ. Angiotensin II-induced vascular remodeling and hypertension involves cathepsin L/V-Mek 1/2 mediated mechanism. J Hypertens 36: E28, 2018.

83. Kalluri R. Basement membranes: structure, assembly and role in tumour angiogenesis. Nat Rev Cancer 3: 422-433, 2003.

84. Kannel WB, Brand N, Skinner JJ, Jr., Dawber TR, and McNamara PM. The relation of adiposity to blood pressure and development of hypertension. The Framingham study. Ann Intern Med 67: 48-59, 1967.

85. Karnik SK, Brooke BS, Bayes-Genis A, Sorensen L, Wythe JD, Schwartz RS, Keating MT, and Li DY. A critical role for elastin signaling in vascular morphogenesis and disease. Development 130: 411-423, 2003.

86. Keeley FW and Johnson DJ. The effect of developing hypertension on the synthesis and accumulation of elastin in the aorta of the rat. Biochem Cell Biol 64: 38-43, 1986.

87. Klatsky AL, Friedman GD, Siegelaub AB, and Gerard MJ. Alcohol consumption and blood pressure. KaiserPermanente Multiphasic Health Examination data. $N$ Engl J Med 296: 1194-1200, 1977.

88. Koffi I, Lacolley P, Kirchengaast M, Pomies JP, Laurent $\mathrm{S}$, and Benetos A. Prevention of arterial structural alterations with verapamil and trandolapril and consequences for mechanical properties in spontaneously hypertensive rats. Eur J Pharmacol 361: 51-60, 1998.

89. Koyama H, Raines EW, Bornfeldt KE, Roberts JM, and Ross R. Fibrillar collagen inhibits arterial smooth muscle proliferation through regulation of Cdk2 inhibitors. Cell 87: 1069-1078, 1996.

90. Krettek A, Sukhova GK, and Libby P. Elastogenesis in human arterial disease: a role for macrophages in disordered elastin synthesis. Arterioscler Thromb Vasc Biol 23: 582-587, 2003.

91. Lacolley P, Regnault V, Segers P, and Laurent S. Vascular smooth muscle cells and arterial stiffening: relevance in development, aging, and disease. Physiol Rev 97: 15551617, 2017.

92. Laurent S and Boutouyrie P. The structural factor of hypertension: large and small artery alterations. Circ Res 116: 1007-1021, 2015. 
93. Laviades C, Varo N, Fernandez J, Mayor G, Gil MJ, Monreal I, and Diez J. Abnormalities of the extracellular degradation of collagen type I in essential hypertension. Circulation 98: 535-540, 1998.

94. Lee SJ, Baek SE, Jang MA, and Kim CD. Osteopontin plays a key role in vascular smooth muscle cell proliferation via EGFR-mediated activation of AP-1 and C/ EBPbeta pathways. Pharmacol Res 108: 1-8, 2016.

95. Lemarie CA, Tharaux PL, and Lehoux S. Extracellular matrix alterations in hypertensive vascular remodeling. J Mol Cell Cardiol 48: 433-439, 2010.

96. Li C, Chang Y, Li Y, Chen S, Chen Y, Ye N, Dai D, and Sun Y. Advanced glycation end products promote the proliferation and migration of primary rat vascular smooth muscle cells via the upregulation of BAG3. Int J Mol Med 39: 1242-1254, 2017.

97. Li DY, Brooke B, Davis EC, Mecham RP, Sorensen LK, Boak BB, Eichwald E, and Keating MT. Elastin is an essential determinant of arterial morphogenesis. Nature 393: 276-280, 1998.

98. Li DY, Toland AE, Boak BB, Atkinson DL, Ensing GJ, Morris CA, and Keating MT. Elastin point mutations cause an obstructive vascular disease, supravalvular aortic stenosis. Hum Mol Genet 6: 1021-1028, 1997.

99. Li W, Li QL, Qin LF, Ali R, Qyang YB, Tassabehji M, Pober BR, Sessa WC, Giordano FJ, and Tellides G. Rapamycin inhibits smooth muscle cell proliferation and obstructive arteriopathy attributable to elastin deficiency. Arterioscler Thromb Vasc Biol 33: 1028-1035, 2013.

100. Lian DW, Lai JQ, Wu YJ, Wang L, Chen YJ, Zhang Y, Boini KM, Huang Y, and Chen Y. Cathepsin B-mediated NLRP3 inflammasome formation and activation in angiotensin II-induced hypertensive mice: role of macrophage digestion dysfunction. Cell Physiol Biochem 50: 1585-1600, 2018.

101. Lin ZW, Wang Z, Zhu GP, Li BW, Xie WL, and Xiang DC. Hypertensive vascular remodeling was inhibited by Xuezhikang through the regulation of Fibulin-3 and MMPs in spontaneously hypertensive rats. Int J Clin Exp Med 8: 2118-2127, 2015.

102. Lind L, Sundstrom J, Arnlov J, and Ingelsson E. Proteomic profiling of endothelium-dependent vasodilation. J Hypertens 37: 216-222, 2019.

103. Lindsey ML, Hall ME, Harmancey R, and Ma YG. Adapting extracellular matrix proteomics for clinical studies on cardiac remodeling post-myocardial infarction. Clin Proteom 13: 19-26, 2016.

104. Lipinski KV, Keul P, Lucke S, Heusch G, Wohschlaeger J, Baba HA, and Levkau B. Degraded collagen induces calpain-mediated apoptosis and destruction of the $\mathrm{X}$-chromosome-linked inhibitor of apoptosis (xIAP) in human vascular smooth muscle cells. Cardiovasc Res 69: 697-705, 2006.

105. Liu H, Dong WP, Lin ZQ, Lu JB, Wan H, Zhou ZX, and Liu ZJ. CCN4 regulates vascular smooth muscle cell migration and proliferation. Mol Cells 36: 112-118, 2013.

106. Lord MS, Chuang CY, Melrose J, Davies MJ, Iozzo RV, and Whitelock JM. The role of vascular-derived perlecan in modulating cell adhesion, proliferation and growth factor signaling. Matrix Biol 35: 112-122, 2014.

107. Lorentzen KA, Chai S, Chen H, Danielsen CC, Simonsen $\mathrm{U}$, and Wogensen L. Mechanisms involved in extracellular matrix remodeling and arterial stiffness induced by hyaluronan accumulation. Atherosclerosis 244: 195-203, 2016.

108. Lovdahl C, Thyberg J, and Hultgardh-Nilsson A. The synthetic metalloproteinase inhibitor batimastat suppresses injury-induced phosphorylation of MAP kinase ERK1/ERK2 and phenotypic modification of arterial smooth muscle cells in vitro. $J$ Vasc Res 37: 345-354, 2000.

109. Lyck Hansen M, Beck HC, Irmukhamedov A, Jensen PS, Olsen MH, and Rasmussen LM. Proteome analysis of human arterial tissue discloses associations between the vascular content of small leucine-rich repeat proteoglycans and pulse wave velocity. Arterioscler Thromb Vasc Biol 35: 1896-1903, 2015.

110. Ma M, Guo X, Chang Y, Li C, Meng X, Li S, Du ZX, Wang HQ, and Sun Y. Advanced glycation end products promote proliferation and suppress autophagy via reduction of Cathepsin D in rat vascular smooth muscle cells. Mol Cell Biochem 403: 73-83, 2015.

111. Mackie EJ, Scottburden T, Hahn AWA, Kern F, Bernhardt $\mathrm{J}$, Regenass S, Weller A, and Buhler FR. Expression of tenascin by vascular smooth-muscle cells-alterations in hypertensive rats and stimulation by angiotensin-II. Am J Pathol 141: 377-388, 1992.

112. Marque V, Kieffer P, Gayraud B, Lartaud-Idjouadiene I, Ramirez F, and Atkinson J. Aortic wall mechanics and composition in a transgenic mouse model of Marfan syndrome. Arterioscler Thromb Vasc Biol 21: 1184-1189, 2001.

113. Martinez-Revelles S, Garcia-Redondo AB, Avendano MS, Varona S, Palao T, Orriols M, Roque FR, Fortuno A, Touyz RM, Martinez-Gonzalez J, Salaices M, Rodriguez $\mathrm{C}$, and Briones AM. Lysyl oxidase induces vascular oxidative stress and contributes to arterial stiffness and abnormal elastin structure in hypertension: role of p38MAPK. Antioxid Redox Signal 27: 379-397, 2017.

114. Maurice P, Blaise S, Gayral S, Debelle L, Laffargue M, Hornebeck W, and Duca L. Elastin fragmentation and atherosclerosis progression: the elastokine concept. Trends Cardiovasc Med 23: 211-221, 2013.

115. McDaniel DP, Shaw GA, Elliott JT, Bhadriraju K, Meuse $\mathrm{C}$, Chung $\mathrm{KH}$, and Plant AL. The stiffness of collagen fibrils influences vascular smooth muscle cell phenotype. Biophys J 92: 1759-1769, 2007.

116. McEniery CM, Wilkinson IB, and Avolio AP. Age, hypertension and arterial function. Clin Exp Pharmacol $P$ 34: 665-671, 2007.

117. Meneton $\mathrm{P}$, Jeunemaitre $\mathrm{X}$, De Wardener HE, and Macgregor GA. Links between dietary salt intake, renal salt handling, blood pressure, and cardiovascular diseases. Physiol Rev 85: 679-715, 2005.

118. Mensah GA. Hypertension and target organ damage: don't believe everything you think! Ethnic Dis 26: 275-278, 2016.

119. Mente A, O’Donnell MJ, Rangarajan S, McQueen MJ, Poirier P, Wielgosz A, Morrison H, Li W, Wang X, Di C, Mony P, Devanath A, Rosengren A, Oguz A, Zatonska K, Yusufali AH, Lopez-Jaramillo P, Avezum A, Ismail N, Lanas F, Puoane T, Diaz R, Kelishadi R, Iqbal R, Yusuf R, Chifamba J, Khatib R, Teo K, and Yusuf S; PURE Investigators. Association of urinary sodium and potassium excretion with blood pressure. $N$ Engl J Med 371: 601-611, 2014. 
120. Mitchell GF, Hwang SJ, Vasan RS, Larson MG, Pencina MJ, Hamburg NM, Vita JA, Levy D, and Benjamin EJ. Arterial stiffness and cardiovascular events: the Framingham Heart Study. Circulation 121: 505-511, 2010.

121. Mochizuki S, Brassart B, and Hinek A. Signaling pathways transduced through the elastin receptor facilitate proliferation of arterial smooth muscle cells. J Biol Chem 277: 44854-44863, 2002.

122. Nehme J, Mercier N, Labat C, Benetos A, Safar ME, Delcayre C, and Lacolley P. Differences between cardiac and arterial fibrosis and stiffness in aldosterone-salt rats: effect of eplerenone. J Renin Angio Aldo S 7: 31-39, 2006.

123. Niemirska A, Litwin M, Trojanek J, Gackowska L, Kubiszewska I, Wierzbicka A, Kułaga Z, and Michałkiewicz J. Altered matrix metalloproteinase 9 and tissue inhibitor of metalloproteinases 1 levels in children with primary hypertension. J Hypertens 34: 1815-1822, 2016.

124. Obama T, Takayanagi T, Kobayashi T, Bourne AM, Elliott KJ, Charbonneau M, Dubois CM, and Eguchi S. Vascular induction of a disintegrin and metalloprotease 17 by angiotensin II through hypoxia inducible factor 1 alpha. Am J Hypertens 28: 10-14, 2015.

125. Odenbach J, Wang X, Cooper S, Chow FL, Oka T, Lopaschuk G, Kassiri Z, and Fernandez-Patron C. MMP-2 mediates angiotensin II-induced hypertension under the transcriptional control of MMP-7 and TACE. Hypertension 57: 123-130, 2011.

126. Oller J, Alfranca A, Mendez-Barbero N, Villahoz S, Lozano-Vidal N, Martin-Alonso M, Arroyo AG, Escolano A, Armesilla AL, Campanero MR, and Redondo JM. $\mathrm{C} / \mathrm{EBPb}$ ta and nuclear factor of activated $\mathrm{T}$ cells differentially regulate adamts-1 induction by stimuli associated with vascular remodeling. Mol Cell Biol 35: 3409-3422, 2015.

127. Onal IK, Altun B, Onal ED, Kirkpantur A, Gul Oz S, and Turgan C. Serum levels of MMP-9 and TIMP-1 in primary hypertension and effect of antihypertensive treatment. Eur J Intern Med 20: 369-372, 2009.

128. Orr AW, Lee MY, Lemmon JA, Yurdagul A, Gomez MF, Bortz PDS, and Wamhoff BR. Molecular mechanisms of collagen isotype-specific modulation of smooth muscle cell phenotype. Arterioscler Thromb Vasc Biol 29: 225231, 2009.

129. Palao T, Rippe C, van Veen H, VanBavel E, Sward K, and Bakker EN. Thrombospondin-4 knockout in hypertension protects small-artery endothelial function but induces aortic aneurysms. Am J Physiol Heart Circ Physiol 310: H1486-H1493, 2016.

130. Palao T, Sward K, Jongejan A, Moerland PD, de Vos J, van Weert A, Arribas SM, Groma G, vanBavel E, and Bakker ENTP. Gene expression and microRNA expression analysis in small arteries of spontaneously hypertensive rats. Evidence for ER stress. PLoS One 10: e0137027, 2015.

131. Panciera T, Azzolin L, Cordenonsi M, and Piccolo S. Mechanobiology of YAP and TAZ in physiology and disease. Nat Rev Mol Cell Biol 18: 758-770, 2017.

132. Peyton SR, Kim PD, Ghajar CM, Seliktar D, and Putnam AJ. The effects of matrix stiffness and RhoA on the phenotypic plasticity of smooth muscle cells in a 3-D biosynthetic hydrogel system. Biomaterials 29: 25972607, 2008.

133. Pichler RH, Hugo C, Shankland SJ, Reed MJ, Bassuk JA, Andoh TF, Lombardi DM, Schwartz SM, Bennett WM,
Alpers CE, Sage EH, Johnson RJ, and Couser WG. SPARC is expressed in renal interstitial fibrosis and in renal vascular injury. Kidney Int 50: 1978-1989, 1996.

134. Post A, Wang E, and Cosgriff-Hernandez E. A Review of integrin-mediated endothelial cell phenotype in the design of cardiovascular devices. Ann Biomed Eng 47: 366-380, 2019.

135. Pushpakumar SB, Kundu S, Metreveli N, Tyagi SC, and Sen U. Matrix metalloproteinase inhibition mitigates renovascular remodeling in salt-sensitive hypertension. Physiol Rep 1: e00063, 2013.

136. Qyang YB. Modeling cardiovascular disease in supravalvular aortic stenosis and Williams-Beuren syndrome using human induced pluripotent stem cells. Circ Res 111: E383, 2012.

137. Raffetto JD and Khalil RA. Matrix metalloproteinases and their inhibitors in vascular remodeling and vascular disease. Biochem Pharmacol 75: 346-359, 2008.

138. Rahkonen O, Su M, Hakovirta H, Koskivirta I, Hormuzdi SG, Vuorio E, Bornstein P, and Penttinen R. Mice with a deletion in the first intron of the Collal gene develop age-dependent aortic dissection and rupture. Circ Res 94: 83-90, 2004.

139. Rodrigo R, Gonzalez J, and Paoletto F. The role of oxidative stress in the pathophysiology of hypertension. Hypertens Res 34: 431-440, 2011.

140. Ryan AJ and O'Brien FJ. Insoluble elastin reduces collagen scaffold stiffness, improves viscoelastic properties, and induces a contractile phenotype in smooth muscle cells. Biomaterials 73: 296-307, 2015.

141. Sahu S, Ganguly R, and Raman P. Upregulation of TSP-1 expression associates with enhanced phenotypic switching of vascular smooth muscle cells in $\mathrm{KKAy}(+/-)$ mice, a mouse model of metabolic syndrome. FASEB $J$ 30: lb582, 2016.

142. Sasamura H, Kitamura Y, Nakamura M, Ryuzaki M, and Saruta T. Effects of the angiotensin receptor blocker (ARB) candesartan on arterial stiffness and markers of extracellular matrix metabolism in patients with essential hypertension. J Hypertens 24: 298, 2006.

143. Sehgel NL, Sun Z, Hong Z, Hunter WC, Hill MA, Vatner DE, Vatner SF, and Meininger GA. Augmented vascular smooth muscle cell stiffness and adhesion when hypertension is superimposed on aging. Hypertension 65: 370377, 2015.

144. Sehgel NL, Zhu Y, Sun Z, Trzeciakowski JP, Hong Z, Hunter WC, Vatner DE, Meininger GA, and Vatner SF. Increased vascular smooth muscle cell stiffness: a novel mechanism for aortic stiffness in hypertension. Am $J$ Physiol Heart Circ Physiol 305: H1281-H1287, 2013.

145. Seo KW, Lee SJ, Ye BH, Kim YW, Bae SS, and Kim CD. Mechanical stretch enhances the expression and activity of osteopontin and MMP-2 via the Akt1/AP-1 pathways in VSMC. J Mol Cell Cardiol 85: 13-24, 2015.

146. Seyrantepe V, Hinek A, Peng J, Fedjaev M, Ernest S, Kadota Y, Canuel M, Itoh K, Morales CR, Lavoie J, Tremblay J, and Pshezhetsky AV. Enzymatic activity of lysosomal carboxypeptidase (cathepsin) a is required for proper elastic fiber formation and inactivation of endothelin-1. Circulation 117: 1973-1981, 2008.

147. Sharifi AM and Schiffrin EL. Apoptosis in aorta of deoxycorticosterone acetate-salt hypertensive rats: effect of endothelin receptor antagonism. J Hypertens 15: 14411448, 1997. 
148. Shen MC, Morton J, Davidge ST, and Kassiri Z. Loss of smooth muscle cell disintegrin and metalloproteinase 17 transiently suppresses angiotensin II-induced hypertension and end-organ damage. J Mol Cell Cardiol 103: 11-21, 2017.

149. Shimojo N, Hashizume R, Kanayama K, Hara M, Suzuki $\mathrm{Y}$, Nishioka $\mathrm{T}$, Hiroe $\mathrm{M}$, Yoshida $\mathrm{T}$, and ImanakaYoshida K. Tenascin-C may accelerate cardiac fibrosis by activating macrophages via the integrin $\alpha \mathrm{V} \beta 3 /$ nuclear factor- $\kappa \mathrm{B} /$ interleukin-6 axis. Hypertension 66: 757-766, 2015.

150. Slove S, Lannoy M, Behmoaras J, Pezet M, Sloboda N, Lacolley P, Escoubet B, Bujan J, and Jacob MP. Potassium channel openers increase aortic elastic fiber formation and reverse the genetically determined elastin deficit in the BN rat. Hypertension 62: 794-801, 2013.

151. Spiers JP, Kelso EJ, Siah WF, Edge G, Song GJ, McDermott BJ, and Hennessy M. Alterations in vascular matrix metalloproteinase due to ageing and chronic hypertension: effects of endothelin receptor blockade. J Hypertens 23: 1717-1724, 2005.

152. Stakos DA, Tziakas DN, Chalikias GK, Mitrousi K, Tsigalou C, and Boudoulas H. Associations between collagen synthesis and degradation and aortic function in arterial hypertension. Am J Hypertens 23: 488-494, 2010.

153. Stegemann C, Didangelos A, Barallobre-Barreiro J, Langley SR, Mandal K, Jahangiri M, and Mayr M. Proteomic identification of matrix metalloproteinase substrates in the human vasculature. Circ Cardiovasc Gene 6: 106-117, 2013.

154. Stein JJ, Iwuchukwu C, Maier KG, and Gahtan V. Thrombospondin-1-induced vascular smooth muscle cell migration and proliferation are functionally dependent on microRNA-21. Surgery 155: 228-233, 2014.

155. Stepien E, Wypasek E, Stopyra K, Konieczynska M, Przybylo M, and Pasowicz M. Increased levels of bone remodeling biomarkers (osteoprotegerin and osteopontin) in hypertensive individuals. Clin Biochem 44: 826-831, 2011.

156. Steppan J, Bergman Y, Viegas K, Armstrong D, Tan S, Wang H, Melucci S, Hori D, Park SY, Barreto SF, Isak A, Jandu S, Flavahan N, Butlin M, An SS, Avolio A, Berkowitz DE, Halushka MK, and Santhanam L. Tissue transglutaminase modulates vascular stiffness and function through crosslinking-dependent and crosslinking-independent functions. J Am Heart Assoc 6: e004161, 2017.

157. Steucke KE, Tracy PV, Hald ES, Hall JL, and Alford PW. Vascular smooth muscle cell functional contractility depends on extracellular mechanical properties. J Biomech 48: 3044-3051, 2015.

158. Sugita S and Matsumoto T. Multiphoton microscopy observations of $3 \mathrm{D}$ elastin and collagen fiber microstructure changes during pressurization in aortic media. Biomech Model Mechanobiol 16: 763-773, 2017.

159. Takasaki I, Chobanian AV, Mamuya WS, and Brecher P. Hypertension induces alternatively spliced forms of fibronectin in rat aorta. Hypertension 20: 20-25, 1992.

160. Theocharis AD, Skandalis SS, Gialeli C, and Karamanos NK. Extracellular matrix structure. Adv Drug Deliv Rev 97: 4-27, 2016.

161. Todorovich-Hunter L, Johnson DJ, Ranger P, Keeley FW, and Rabinovitch M. Altered elastin and collagen synthesis associated with progressive pulmonary hypertension induced by monocrotaline. A biochemical and ultrastructural study. Lab Invest 58: 184-195, 1988.
162. Touyz RM, Alves-Lopes R, Rios FJ, Camargo LL, Anagnostopoulou A, Arner A, and Montezano AC. Vascular smooth muscle contraction in hypertension. Cardiovasc Res 114: 529-539, 2018.

163. Urban Z, Riazi S, Seidl TL, Katahira J, Smoot LB, Chitayat D, Boyd CD, and Hinek A. Connection between elastin haploinsufficiency and increased cell proliferation in patients with supravalvular aortic stenosis and WilliamsBeuren syndrome. Am J Hum Genet 71: 30-44, 2002.

164. Virdis A, Neves MF, Amiri F, Touyz RM, and Schiffrin EL. Role of $\mathrm{NAD}(\mathrm{P}) \mathrm{H}$ oxidase on vascular alterations in angiotensin II-infused mice. J Hypertens 22: 535-542, 2004.

165. Wagenseil JE and Mecham RP. Elastin in large artery stiffness and hypertension. J Cardiovasc Transl Res 5: 264-273, 2012.

166. Wagenseil JE and Mecham RP. Vascular extracellular matrix and arterial mechanics. Physiol Rev 89: 957-989, 2009.

167. Walker-Caprioglio HM, Koob TJ, and McGuffee LJ. Proteoglycan synthesis in normotensive and spontaneously hypertensive rat arteries in vitro. Matrix 12: 308320, 1992.

168. Wang B, Zhang JD, Feng JB, Yin HQ, Liu FY, and Wang Y. Effect of traditional Chinese medicine Qin-Dan-JiangYa-Tang on remodeled vascular phenotype and osteopontin in spontaneous hypertensive rats. J Ethnopharmacol 110: 176-182, 2007.

169. Wang M, Fu Y, Gao C, Jia Y, Huang Y, Liu L, Wang X, Wang W, and Kong W. Cartilage oligomeric matrix protein prevents vascular aging and vascular smooth muscle cells senescence. Biochem Biophys Res Commun 478: 1006-1013, 2016.

170. Wang M, Kim SH, Monticone RE, and Lakatta EG. Matrix metalloproteinases promote arterial remodeling in aging, hypertension, and atherosclerosis. Hypertension 65: 698-703, 2015.

171. Wang X, Chow FL, Oka T, Hao L, Lopez-Campistrous A, Kelly S, Cooper S, Odenbach J, Finegan BA, Schulz R, Kassiri Z, Lopaschuk GD, and Fernandez-Patron C. Matrix metalloproteinase-7 and ADAM-12 (a disintegrin and metalloproteinase-12) define a signaling axis in agonist-induced hypertension and cardiac hypertrophy. Circulation 119: 2480-2489, 2009.

172. Wang X, Oka T, Chow FL, Cooper SB, Odenbach J, Lopaschuk GD, Kassiri Z, and Fernandez-Patron C. Tumor necrosis factor-alpha-converting enzyme is a key regulator of agonist-induced cardiac hypertrophy and fibrosis. Hypertension 54: 575-582, 2009.

173. Watson KE, Parhami F, Shin V, and Demer LL. Fibronectin and collagen I matrixes promote calcification of vascular cells in vitro, whereas collagen IV matrix is inhibitory. Arterioscler Thromb Vasc Biol 18: 1964-1971, 1998.

174. Watts SW, Rondelli C, Thakali K, Li XP, Uhal B, Pervaiz MH, Watson RE, and Fink GD. Morphological and biochemical characterization of remodeling in aorta and vena cava of DOCA-salt hypertensive rats. Am J Physiol Heart Circ Physiol 292: H2438-H2448, 2007.

175. Wu J, Montaniel KR, Saleh MA, Xiao L, Chen W, Owens GK, Humphrey JD, Majesky MW, Paik DT, Hatzopoulos AK, Madhur MS, and Harrison DG. Origin of matrixproducing cells that contribute to aortic fibrosis in hypertension. Hypertension 67: 461-468, 2016. 
176. Xie SA, Zhang T, Wang J, Zhao F, Zhang YP, Yao WJ, Hur SS, Yeh YT, Pang W, Zheng LS, Fan YB, Kong W, Wang X, Chiu JJ, and Zhou J. Matrix stiffness determines the phenotype of vascular smooth muscle cell in vitro and in vivo: role of DNA methyltransferase 1. Biomaterials 155: 203-216, 2018.

177. Xu J and Shi GP. Vascular wall extracellular matrix proteins and vascular diseases. Biochim Biophys Acta 1842: 2106-2119, 2014.

178. Xu J-W, Li Y-L, Zhang S-J, Yang W-Q, Nie W-T, and Jiang H-Q. Quantitative serum proteomic analysis of essential hypertension using iTRAQ technique. Biomed Res Int 2017: 1-12, 2017.

179. Xu YC, Appay MD, Heudes D, Lemoine R, Hinglais N, Michel JB, and Bariety J. Colocalization of collagen overexpression and inflammatory cell infiltration in the two-kidney one-clip rat model from the early days of hypertension onward. Virchows Arch 432: 267-277, 1998.

180. Yamada E, Hazama F, Amano S, Sasahara M, and Kataoka H. Elastase, collagenase, and cathepsin D activities in the aortas of spontaneously hypertensive and renal hypertensive rats. Exp Mol Pathol 44: 147-156, 1986.

181. Yanagisawa H, Davis EC, Starcher BC, Ouchi T, Yanagisawa M, Richardson JA, and Olson EN. Fibulin-5 is an elastin-binding protein essential for elastic fibre development in vivo. Nature 415: 168-171, 2002.

182. Yang L, Li L, Lewington S, Guo Y, Sherliker P, Bian Z, Collins R, Peto R, Liu Y, Yang R, Zhang Y, Li G, Liu S, and Chen Z; China Kadoorie Biobank Study Colloboration. Outdoor temperature, blood pressure, and cardiovascular disease mortality among 23000 individuals with diagnosed cardiovascular diseases from China. Eur Heart J 36: 1178-1185, 2015.

183. Yasmin, Maskari RA, McEniery CM, Cleary SE, Li Y, Siew K, Figg NL, Khir AW, Cockcroft JR, Wilkinson IB, and O'Shaughnessy KM. The matrix proteins aggrecan and fibulin-1 play a key role in determining aortic stiffness. Sci Rep 8: 8550, 2018.

184. Yasmin, McEniery CM, Wallace S, Dakham Z, Pusalkar $\mathrm{P}$, Maki-Petaja K, Ashby MJ, Cockcroft JR, and Wilkinson IB. Matrix metalloproteinase-9 (MMP-9), MMP-2, and serum elastase activity are associated with systolic hypertension and arterial stiffness (vol 25, pg 372, 2005). Arterioscler Thromb Vasc Biol 25: 875-875, 2005.

185. You B, Shen L, Li J, Chen Y, Gu X, and Gao H. The correlation between carotid-femoral pulse wave velocity and composition of the aortic media in CAD patients with or without hypertension. Swiss Med Wkly 142: w13546, 2012.

186. Zacchigna L, Vecchione C, Notte A, Cordenonsi M, Dupont S, Maretto S, Cifelli G, Ferrari A, Maffei A, Fabbro C, Braghetta P, Marino G, Selvetella G, Aretini A, Colonnese C, Bettarini U, Russo G, Soligo S, Adorno M, Bonaldo P, Volpin D, Piccolo S, Lembo G, and Bressan GM. Emilin1 links TGF-beta maturation to blood pressure homeostasis. Cell 124: 929-942, 2006.

187. Zervoudaki A, Economou E, Pitsavos C, Vasiliadou K, Aggeli C, Tsioufis K, Toutouza M, Stefanadis C, and Toutouzas $\mathrm{P}$. The effect of $\mathrm{Ca}^{2+}$ channel antagonists on plasma concentrations of matrix metalloproteinase- 2 and9 in essential hypertension. Am J Hypertens 17: 273-276, 2004.

188. Zervoudaki A, Economou E, Stefanadis C, Pitsavos C, Tsioufis K, Aggeli C, Vasiliadou K, Toutouza M, and Toutouzas P. Plasma levels of active extracellular matrix metalloproteinases 2 and 9 in patients with essential hypertension before and after anti hypertensive treatment. J Hum Hypertens 17: 119-124, 2003.

189. Zhong ZY and Tang Y. Upregulation of periostin prevents high glucose-induced mitochondrial apoptosis in human umbilical vein endothelial cells via activation of Nrf2/HO1 signaling. Cell Physiol Biochem 39: 71-80, 2016.

190. Zhu R, Cheng M, Lu T, Yang N, Ye S, Pan Y-H, Hong T, Dang S, and Zhang W. A Disintegrin and metalloproteinase with thrombospondin motifs 18 deficiency leads to visceral adiposity and associated metabolic syndrome in mice. Am J Pathol 188: 461-473, 2018.

191. Zieman SJ, Melenovsky V, and Kass DA. Mechanisms, pathophysiology, and therapy of arterial stiffness. Arterioscler Thromb Vasc Biol 25: 932-943, 2005.

192. Zunke F and Rose-John S. The shedding protease ADAM17: physiology and pathophysiology. Biochim Biophys Acta Mol Cell Res 1864: 2059-2070, 2017.

Address correspondence to: Dr. $\mathrm{Li} \mathrm{Li}$ Department of Physiology and Pathophysiology Peking University Health Science Center

38 Xueyuan Road Beijing 100191 P.R. China

E-mail: lilyby@163.com

Prof. Wei Kong

Department of Physiology and Pathophysiology Peking University Health Science Center 38 Xueyuan Road Beijing 100191

P.R. China

E-mail: kongw@bjmu.edu.cn

Date of first submission to ARS Central, April 16, 2020; date of acceptance, April 24, 2020.

\section{Abbreviations Used}

ACEIs $=$ angiotensin-converting enzyme inhibitors $\mathrm{ADAMTS}=\mathrm{a}$ disintegrin and metalloproteinase with thrombospondin motifs

Ang II = angiotensin II

AP-1 = activator protein-1

$\mathrm{ARBs}=$ angiotensin receptor blockers

$\mathrm{BM}=$ basement membrane

$\mathrm{BP}=$ blood pressure

$\mathrm{CCBs}=$ calcium channel blockers

$\mathrm{CCN}=\mathrm{Cyr} 61 / \mathrm{CTGF} / \mathrm{NOV}$

C/EBP $\beta=$ CCAAT-enhancer-binding protein $\beta$

$\mathrm{CTGF}=$ connective tissue growth factor

DOCA $=$ deoxycorticosterone acetate

$\mathrm{EC}=$ endothelial cell

$\mathrm{ECM}=$ extracellular matrix

EDPs $=$ elastin-derived peptides

$\mathrm{ERC}=$ elastin receptor complex

ERK1/2 = extracellular signal-regulated kinase $1 / 2$ $\mathrm{HF}=$ heart failure 


\section{Abbreviations Used (Cont.)}

ICTP $=$ carboxy-terminal telopeptide of type I collagen

$\mathrm{IEL}=$ internal elastic lamina

$\mathrm{IL}=$ interleukin

LOX $=$ lysyl oxidase

MAPK $=$ mitogen-activated protein kinase

MMPs $=$ matrix metalloproteinases

$\mathrm{mTOR}=$ mammalian target of rapamycin

$\mathrm{NF}-\kappa \mathrm{B}=$ nuclear factor $-\kappa \mathrm{B}$

NLRP3 $=$ NOD, LRR, and pyrin domain-containing protein 3

$\mathrm{NO}=$ nitric oxide

$\mathrm{OPN}=$ osteopontin
$\mathrm{PG}=$ proteoglycan

$\mathrm{PICP}=$ procollagen type $\mathrm{I} \mathrm{C}$-terminal propeptide

$\mathrm{PWV}=$ pulse wave velocity

ROS $=$ reactive oxygen species

$\mathrm{SHR}=$ spontaneously hypertensive rats

SHR-SP $=$ stroke-prone spontaneously hypertensive rats $\mathrm{SMC}=$ smooth muscle cell

TGF- $\beta=$ transforming growth factor- $\beta$

TIMPs $=$ tissue inhibitors of metalloproteinases

$\mathrm{TNC}=$ tenascin $\mathrm{C}$

TNF- $\alpha=$ tumor necrosis factor- $\alpha$

TSPs $=$ thrombospondins

$\mathrm{VSMC}=$ vascular smooth muscle cell

$\mathrm{YAP}=$ Yes-associated protein 